\title{
Analisis Penerimaan Google Classroom Menggunakan Pendekatan Technology Acceptance Model (TAM) dan End-User Computing Satisfaction (EUCS)
}

\author{
Zatin Niqotaini*, Budiman \\ Program Studi Sistem Informasi, Fakultas Teknologi dan Informatika, \\ Universitas Informatika dan Bisnis Indonesia \\ Jalan Soekarno Hatta No.643 Bandung, Jawa Barat, Indonesia \\ *e-mail: zatinniqotaini@gmail.com
}

(received: 8 April 2021,revised: 22 Juni 2021, accepted: 20 Juli 2021)

\begin{abstract}
Abstrak
Pandemi virus corona (COVID-19) memberikan dampak besar terhadap berbagai aktivitas manusia di seluruh dunia khususnya negara Indonesia, salah satunya aktivitas pendidikan dan kegiatan pembelajaran di kampus. Kebijakan dari pemerintah tentang WFH (work from home) menjadikan proses kegiatan pembelajaran secara tatap muka di kampus dihentikan sementara sejak bulan Maret 2020 hingga waktu yang belum dapat ditentukan. Universitas Informatika dan Bisnis Indonesia sebagai salah satu institusi pendidikan swasta di Jawa Barat, dituntut untuk mengikuti perubahan metode pembelajaran yaitu pembelajaran jarak jauh (online) yang sebelumnya menggunakan tatap muka secara langsung. Salah satu platform yang banyak digunakan adalah google classroom. Google classroom merupakan aplikasi yang memungkinkan terbentuknya kelas di dunia maya, sebagai salah satu platform yang banyak digunakan tentunya perlu diperlukan evaluasi kepuasaan pengguna terutama mahasiswa agar terdapat perbaikan kedepannya. Penelitian ini dikaji dengan menggunakan model Technology Acceptance Model (TAM) dengan mempertimbangkan faktor Persepsi Kegunaan (Perceived Usefulness), Persepsi Kemudahan Penggunaan (Perceived Ease Of Use) dan Sikap Terhadap Perilaku (Attitude Toward Using). End-User Computing Satisfaction (EUCS) dengan mempertimbangkan Isi (Content), Akurasi (Accuracy), Tampilan (Format), Kemudahan (Ease) dan Ketepatan Waktu (Timeliness). Subyek penelitian yang digunakan adalah mahasiswa di lingkungan Universitas Informatika dan Bisnis Indonesia (Unibi). Hipotesis yang menghasilkan hubungan antar konstruk di dalam TAM dan EUCS diukur dengan Structural Equation Model (SEM) dan software AMOS 26. Hasil penelitian ini menunjukkan bahwa model TAM dan EUCS dapat menjelaskan faktor - faktor yang mempengaruhi penerimaan google classroom pada Unibi dimana Perceived Usefullness (PU) dipengaruhi oleh Perceived Ease of Use (PEOU) 52,2\%. Attitude Toward Using (AT) dipengaruhi oleh Perceived Usefullness (PU) 34,4\%, Content (CT) 25,4\%, Accuracy (AC) 11,9\%, dan Format (FT) $18,4 \%$.
\end{abstract}

Kata kunci : e-learning, google classroom, technology acceptance model (TAM), end user computing satisfaction (EUCS)

Abstract
Coronavirus pandemic (COVID-19) has a big impact on various human activities around the world,
especially indonesia, one of which is educational activities and learning activities on campus. The
government's policy on WFH (work from home) has temporarily suspended the process of face-to-face
learning on campus from March 2020 until an indefinite period of time. University Informatics and
Business Indonesia as one of the private educational institutions in West Java, is required to follow
the changes in learning methods, namely distance learning (online) that previously used face-to-face.
One of the widely used platforms is google classroom. Google classroom is an application that allows
the formation of classes in cyberspace, as one of the widely used platforms of course need to evaluate
user satisfaction, especially students in order for there to be improvements in the future. This study
was reviewed using Technology Acceptance Model (TAM) model taking into account Perceived
Usefulness, Perceived Ease Of Use and Attitude Toward Using. End-User Computing Satisfaction
(EUCS) taking into account Content, Accuracy, Display (Format), Ease and Timeliness. The subjects
http://sistemasiftik.unisiac.id 
of the study used were students in University Informatics and Business Indonesia environment. Hypotheses that produce relationships between constructs within TAM and EUCS are measured by structural equation models (SEM) and AMOS 26 software. The results of this study showed that tam and EUCS models can explain the factors that influence the acceptance of google classroom in Unibi where Perceived Usefullness (PU) is influenced by Perceived Ease of Use (PEOU) 52.2\%. Attitude Toward Using (AT) was influenced by Perceived Usefullness (PU) 34.4\%, Content (CT) 25.4\%, Accuracy (AC) $11.9 \%$, and Format (FT) $18.4 \%$.

Keywords: e-learning, google classroom, technology acceptance model (TAM), end user computing satisfaction (EUCS).

\section{Pendahuluan}

Pembelajaran daring merupakan sistem pembelajaran yang dilakukan dengan tidak bertatap muka langsung, tetapi menggunakan platform yang dapat membantu proses belajar mengajar yang dilakukan meskipun jarak jauh. Tujuan dari adanya pembelajaran daring ialah memberikan layanan pembelajaran bermutu dalam jaringan yang bersifat masif dan terbuka untuk menjangkau peminat ruang belajar agar lebih banyak dan lebih luas [1]. Dosen dan mahasiswa juga bisa berkomunikasi secara interaktif melalui pembelajaran tersebut yang difasilitasi dengan komputer, internet atau smartphone.

Sebagai upaya untuk mendukung proses pembelajaran secara online, serta meningkatkan mutu pembelajaran, Universitas Informatika dan Bisnis Indonesia berupaya memberikan hasil yang terbaik terutama penggunaan teknologi baru. Salah satu cara dalam pelaksanaan proses pembelajaran secara online dengan menggunakan Google Classroom. Google Classroom adalah layanan berbasis internet yang disediakan oleh Google sebagai sebuah sistem e-learning. Service ini didesain untuk membantu pengajar membuat dan membagikan tugas kepada pelajar secara paperless [2]. Pada prosesnya ditemukan beberapa masalah pengguna terutama mahasiswa yang merasa kesulitan dalam mengoperasikan platform ini, sehingga memunculkan konflik dan perbedaan pendapat mengenai platform e-learning manakah yang lebih mudah dan lebih baik untuk digunakan.

Penerapan teknologi baru dalam suatu organisasi bukanlah hal yang mudah diterapkan karena penerapan teknologi baru akan berpengaruh pada keseluruhan organisasi, terutama sumber daya manusia. Faktor pengguna sangat penting diperhatikan dalam penerapan sistem yang baru, karena tingkat kesiapan pengguna untuk menerima sistem yang baru memiliki pengaruh besar dalam menentukan sukses tidaknya penerapan sistem tersebut. Dari permasalahan di atas maka dibutuhkan suatu metode yang mampu menganalisis, mengukur dan menggali sejauh mana penerimaan sistem informasi penting dalam organisasi atau perusahaan.

Tingkat penerimaan pengguna terhadap penerapan penggunaan Google Classroom di Universitas Informatika dan Bisnis Indonesia dapat diukur dengan pendekatan teori yang dapat menggambarkan tingkat penerimaan dan penggunaan terhadap suatu teknologi yaitu teori gabungan Technology Acceptance Model (TAM) dan End-User Computing Satisfaction (EUCS). Melalui teori gabungan TAM dan EUCS, dapat dipahami bahwa reaksi dan persepsi pengguna terhadap teknologi dapat mempengaruhi sikapnya dalam penerimaan penggunaan teknologi.

Penelitian TAM dan EUCS pernah dilakukan oleh beberapa peneliti antara lain Evi Yulianingsih pada tahun 2016 [3] menggunakan TAM dan EUSC untuk menganalisis penerimaan penerapan $e$ learning dibeberapa Perguruan Tinggi Kota Palembang. Khairun Nisa \& Ilhamsyah pada tahun 2020 [4] menggunakan TAM dan EUCS untuk menganalisis penerimaan Siakad di Universitas Tanjungpura. Hadisuwarno \& Bisma [5] menggunakan TAM dan EUCS untuk menganalisis penerimaan pengguna terhadap aplikasi e-Kinerja pada kepolisian.

Penerapan sistem ditentukan oleh faktor-faktor yang mempengaruhi penerimaan pengguna atas teknologi informasi. Dirasakan juga oleh Universitas Informatika dan Bisnis Indonesia harus melakukan pengukuran atas keberhasilan implementasi platform google scholar untuk mendukung proses pembelajaran secara online, serta meningkatkan mutu pembelajaran. Disisi lain Universitas Informatika dan Bisnis Indonesia juga harus mempertimbangkan aspek manusia yang sangat penting disamping aspek teknologi. 
Berdasarkan uraian latar belakang masalah di atas, maka peneliti bermaksud untuk melakukan penelitian dengan menganalisa atau mengidentifikasi faktor-faktor apa saja yang mempengaruhi perilaku pengguna. Berjudul "Analisis Penerimaan Google Classroom Menggunakan Pendekatan Technology Acceptance Model (TAM) Dan End-User Computing Satisfaction (EUCS) (Studi Kasus: Universitas Informatika Dan Bisnis Indonesia)".

\section{Tinjauan Literatur}

\section{A. E-learning}

Beberapa istilah yang digunakan untuk e-learning adalah : internet-based learning (belajar berbasis internet), virtual learning (belajar melalui lingkungan maya), web-based learning (belajar berbasis web). Tentu saja istilah e-learning ini mengacu pada penggunaan teknologi internet untuk menyajikan sejumlah pilihan solusi yang sangat luas (a broad array of solution) yang mengarah pada peningkatan pengetahuan dan performans.

E-learning adalah sarana pendidikan yang mencakup motivasi diri sendiri, komunikasi, efisiensi, dan teknologi. Karena ada keterbatasan dalam interaksi sosial, siswa harus menjaga diri mereka tetap termotivasi. E-learning efisien karena mengeliminasi jarak dan arus pulang-pergi. Jarak dieliminasi karena isi dari elearning didesain dengan media yang dapat diakses dari terminal komputer yang memiliki peralatan yang sesuai dan sarana teknologi lainnya yang dapat mengakses jaringan atau Internet.

Definisi e-learning memiliki beberapa elemen tentang what (apa), when (bagaimana), dan why (mengapa) dari e-learning [6]

a. What (apa) E-learning memasukkan baik konten, yaitu informasi, dan metode instruksional, yaitu teknik, yang membantu orang mempelajari konten belajar.

b. When (bagaimana) E-learning didistribusikan melalui komputer dalam bentuk kalimat dan gambar. Pendistribusiannya dapat dalam bentuk asynchronous yang didesain untuk belajar secara individu dan dalam synchronous yang didesain dengan bimbingan dari instruktur secara langsung.

c. Why (mengapa) E-learning ditujukan untuk membantu pelajar mencapai tujuan belajarnya atau melakukan pekerjaannya.

Terminologi yang berhubungan dengan e-learning sebenarnya banyak, ada online learning, software learning, multimedia learning, computer based learning. Dapat dikatakatan semua bisa diwakili oleh e-learning, baik dalam perspektif umum (online learning, compute based learning) maupun dalam perspektif komponen e-learning (multimedia learning sebagai komponen e-learning content dan software learning sebagai komponen e-learning system).

\section{B. Google Classroom}

Google Classroom adalah aplikasi layanan pembelajaran yang dapat diakses secara gratis untuk keperluan akademik dan organisasi nirlaba. Siapa pun dapat mengakses fitur Google Classroom selama meraka memiliki akun google. Google Classroom sendiri dapat diakses secara multiplatform baik menggunakan komputer desktop maupun perangkat yang bersifat mobile seperti nootebook ataupun smatphone, dan mampu berjalan di beberapa sistem operasi seperti android, ios, windows dan lain sebagainya.[7]

Berikut adalah beberapa Fitur utama dari Google Classroom diantaranya:

a. Assignment (task)

Tugas disimpan dan diberi peringkat dalam serangkaian aplikasi produktivitas Google, memungkinkan kolaborasi antara dosen dan mahasiswa.

b. Rating(measurement)

Google Classroom mendukung banyak hal skema penilaian yang berbeda. Dosen dapat memilih untuk melampirkan file ke tugas di mana mahasiswa dapat melihat, mengedit, atau mendapatkan satu salinan.

c. Communication

Dosen dapat memasang buletin di jalan aliran, dan mahasiswa dapat memberikan komentar itu memungkinkan pertukaran verbal dua arah antara dosen dan mahasiswa. 


\section{Technology Acceptance Model (TAM)}

Model penerimaan teknologi (Technology Acceptance Model atau TAM) merupakan suatu model penerimaan sistem teknologi informasi yang akan digunakan oleh pemakai. Model penerimaan teknologi dikembangkan oleh Davis et al [3] berdasarkan model TRA. Model TRA dapat ditetapkan karena keputusan yang dilakukan oleh individu untuk menerima suatu teknologi sistem informasi merupakan tindakan sadar yang dapat dijelaskan dan diprediksi oleh minat perilakunya.

TAM menambahkan dua konstruk utama ke dalam model TRA. Dua konstruk utama ini adalah persepsi kegunaan (perceived usefulness) dan persepsi kemudahan penggunaan (perceived ease of use). TAM beragumentasi bahwa penerimaan individual terhadap sistem teknologi informasi ditentukan oleh dua konstruk tersebut. Persepsi kegunaan (perceived usefulness) dan persepsi kemudahan penggunaan (perceived ease of use) keduanya mempunyai pengaruh ke minat perilaku (behavioral intention). Pemakai teknologi akan mempunyai minat menggunakan teknologi (minat perilaku) jika merasa sistem teknologi bermanfaat dan mudah digunakan.

Persepsi kegunaan (perceived usefulness) juga mempengaruhi persepsi kemudahan penggunaan (perceived ease of use) tetapi tidak sebaliknya. Pemakai sistem akan menggunakan sistem jika sistem bermanfaat baik sistem itu mudah digunakan atau tidak mudah digunakan. Sistem yang sulit digunakan akan tetap digunakan jika pemakai merasa bahwa sistem masih berguna.

Berikut ini adalah model TAM yang akan digunakan dalam penelitian.

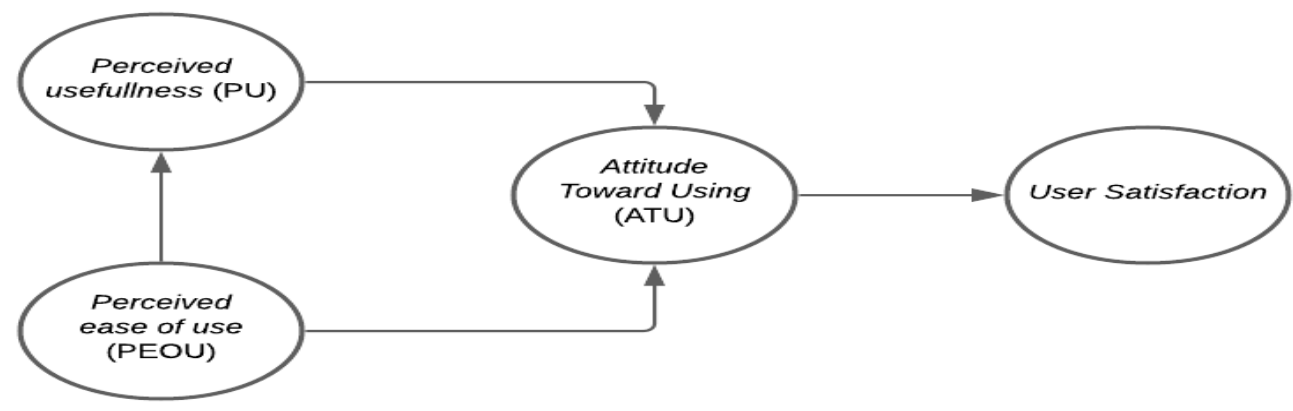

Gambar 1. TAM untuk Kepuasan Pengguna

\section{End User Computing Satisfaction (EUCS)}

Model lain dikembangkan oleh Doll dan Torkzadeh [3] yaitu End User Computing Satisfaction (EUCS). Model EUCS digunakan mengukur kepuasan pemakai terhadap sistem informasi. Sistem informasi suatu organisasi dapat diandalkan apabila memiliki kualitas yang baik dan mampu memberikan kepuasan pada pemakainya. Dengan adanya kepuasan pemakai tersebut maka akan timbul penerimaan (acceptance) pada sistem informasi yang dipergunakan dalam organisasi tersebut. Kepuasan pemakai (user satisfaction) merupakan salah satu indikator dari keberhasilan pengembangan sistem informasi.

Doll dan Torkzadeh mengembangkan instrumen EUCS yang meliputi 5 komponen yaitu terdiri dari: Isi (content), Akurasi (accuracy), Bentuk (format), Kemudahan (ease) dan Ketepatan Waktu (timeliness). Berikut dibawah ini gambar instrument EUCS. 


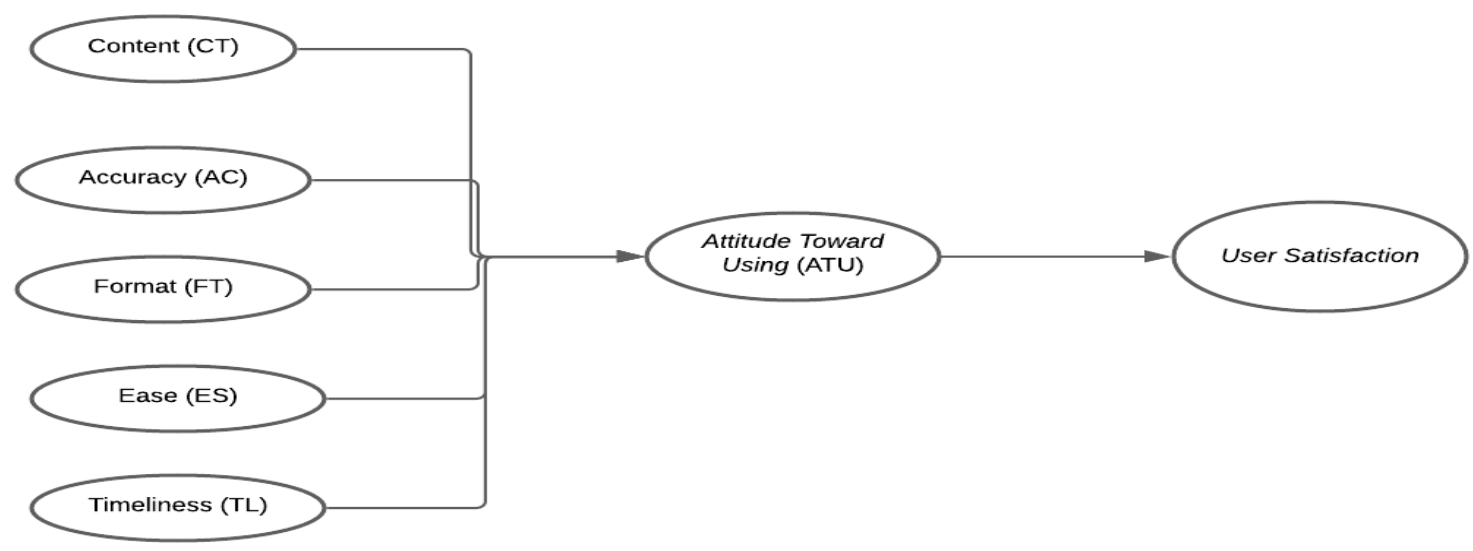

Gambar 2. End User Computing Satisfaction (EUCS)

\section{E. Kerangka Penelitian}

Kerangka penelitian ini, disusun berdasarkan jenis penelitian kuantitatif yang digunakan, dengan menggabungkan 2 (dua) model sebagai kerangka penelitian yaitu Technology Acceptance Model (TAM) dan End User Computing Satisfaction (EUCS). Konsep yang dibangun oleh peneliti ini dalam melakukan penelitian fokus pada penerimaan google classroom.

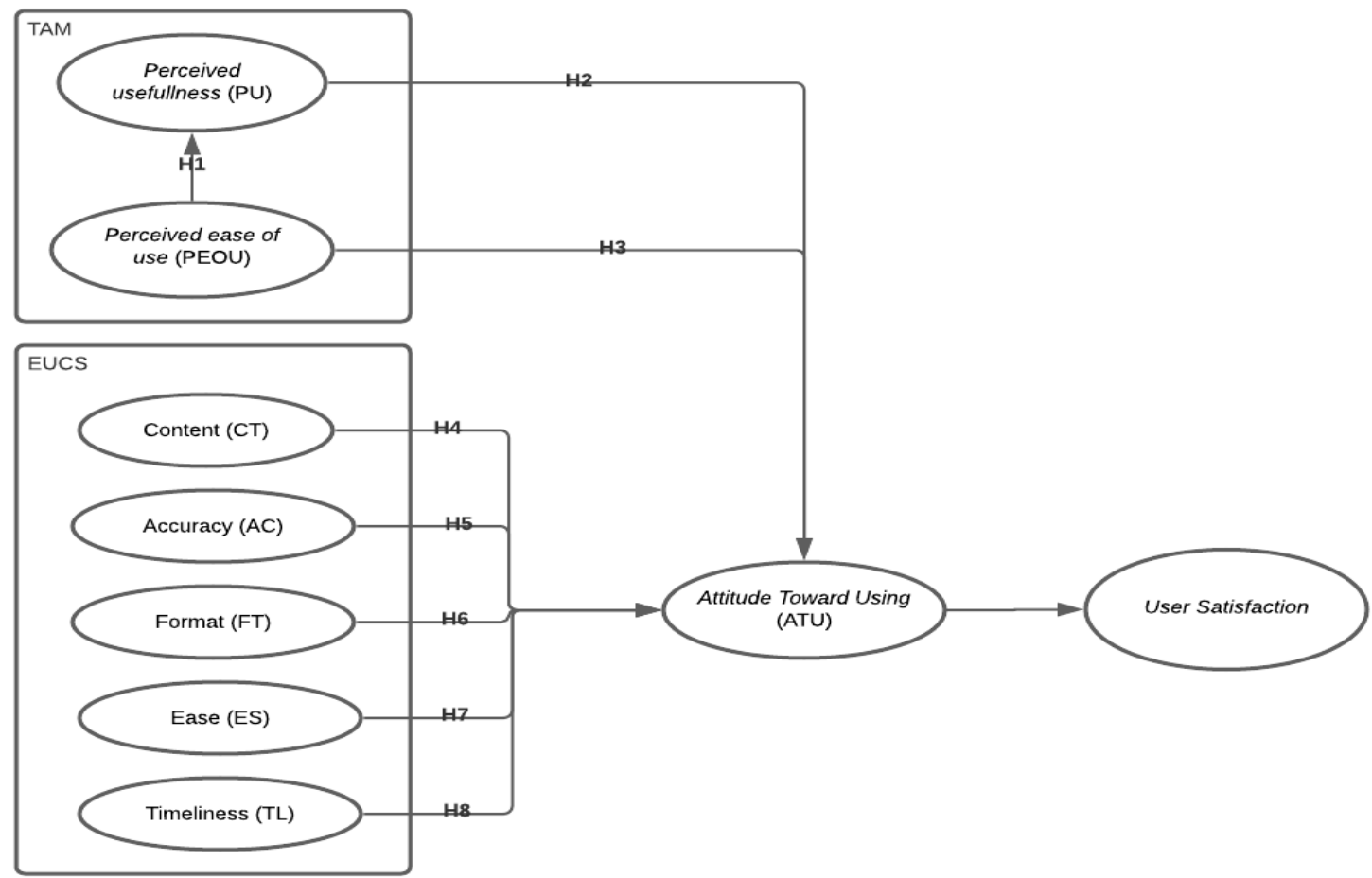

Gambar 3. Kerangka Penelitian 
Berdasarkan gambar 3 diatas, dapat ditarik kesimpulan hipotesis sebagai berikut :

Tabel 1. Hipotesis Penelitian

\begin{tabular}{|c|l|}
\hline No & \multicolumn{1}{|c|}{ Hipotesis } \\
\hline H1 & $\begin{array}{l}\text { Persepsi kemudahan pengguna (perceived ease of use) mempunyai } \\
\text { pengaruh positif terhadap persepsi kegunaan (perceived usefulness) dalam } \\
\text { penggunaan google classroom }\end{array}$ \\
\hline H2 & $\begin{array}{l}\text { Persepsi kegunaan (perceived usefulness) mempunyai pengaruh positif } \\
\text { terhadap sikap terhadap perilaku (attitude towards using) dalam } \\
\text { penggunaan google classroom. }\end{array}$ \\
\hline H3 & $\begin{array}{l}\text { Persepsi kemudahan pengguna (perceived ease of use) mempunyai } \\
\text { pengaruh positif terhadap sikap terhadap perilaku (attitude towards using) } \\
\text { dalam penggunaan google classroom. }\end{array}$ \\
\hline H4 & $\begin{array}{l}\text { Isi (content) mempunyai pengaruh positif terhadap sikap terhadap } \\
\text { perilaku } \\
\text { (attitude towards using) dalam penggunaan google classroom }\end{array}$ \\
\hline H5 & $\begin{array}{l}\text { Keakuratan (accuracy) mempunyai pengaruh positif terhadap sikap } \\
\text { terhadap perilaku (attitude towards using) dalam penggunaan google } \\
\text { classroom }\end{array}$ \\
\hline H6 & $\begin{array}{l}\text { Tampilan (format) mempunyai pengaruh positif terhadap sikap terhadap } \\
\text { perilaku (attitude towards using) dalam penggunaan google classroom }\end{array}$ \\
\hline H7 & $\begin{array}{l}\text { Kemudahan (ease) mempunyai pengaruh positif terhadap sikap terhadap } \\
\text { perilaku (attitude towards using) dalam penggunaan google classroom. }\end{array}$ \\
\hline H8 & $\begin{array}{l}\text { Ketetapan Waktu (timeliness) mempunyai pengaruh positif terhadap sikap } \\
\text { terhadap perilaku (attitude towards using) dalam penggunaan google } \\
\text { classroom. }\end{array}$ \\
\hline
\end{tabular}

\section{Metode Penelitian}

Penelitian ini dilakukan untuk menganalisa bagaimana penerimaan Google Clasroom dengan menggunakan Model TAM dan EUCS. Target penelitian dalam penelitian ini adalah mahasiswa Universitas Informatika dan Bisnis Indonesia. Pengumpulan data yang dibutuhkan dalam penelitian ini adalah menggunakan data primer dengan kuisioner secara online.

\section{A. Tahapan Penelitian}

Adapun tahapan penelitian tentang penerimaan Google Classroom dapat dilihat pada Gambar 4 : 


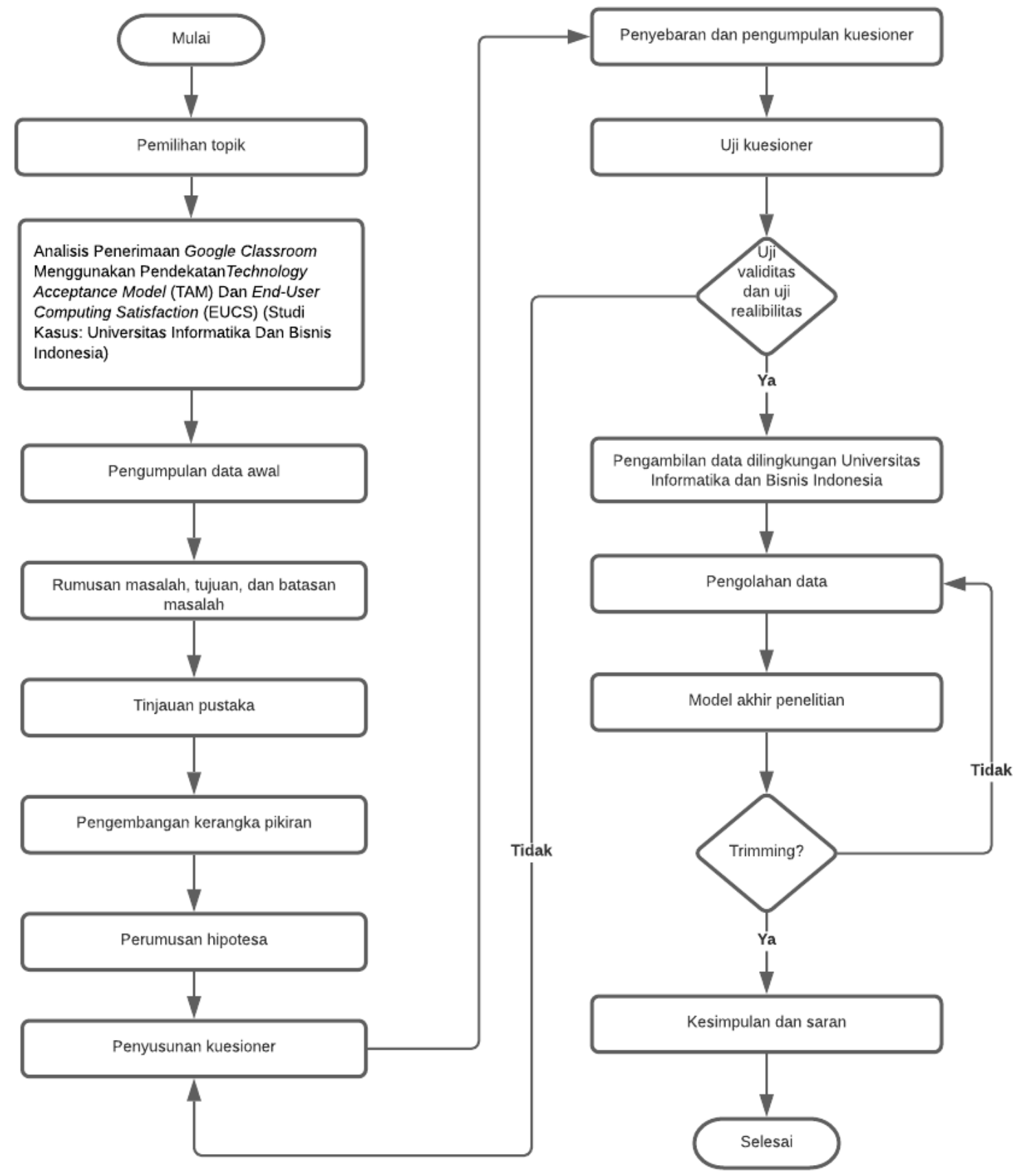

\section{Gambar 4. Tahapan Penelitian}

Tahapan penelitian ini dapat dijelaskan secara umum sebagai berikut : a.) Identifikasi Minat Penelitian dilanjutkan pemilihan topik; b.) Pengumpulan data awal di lakukan dengan studi literatur mengenai minat penelitian terkait (model-model penerimaan dan penelitian-penelitian terdahulu mengenai penerimaan teknologi); c.) Perumusan Masalah dengan melihat keadaan saat ini yang menjadi permasalahan diperoleh dan beberapa fakta-fakta yang ada. Kemudian dirumuskan masalahnya oleh peneliti; d.) Tinjauan Pustaka dengan melakukan studi literatur yang lebih intensif mengenai teori penelitian-penelitian sebelumnya dan metodologi yang relevan dengan topik pembahasan penelitian ini; e.) Pengembangan kerangka pemikiran dilakukan dengan cara membandingkan dan mencari persamaan dengan penelitian terdahulu yang berkaitan dengan tingkat 
penerimaan sistem informasi kuesioner; f.) Perumusan Hipotesis dilakukan dengan acuan variabelvariabel yang dibentuk pada kerangka pemikiran; g.) Tahapan ini dimulai dengan melakukan penyusunan kuesioner, pertanyaan-pertanyaan pada kuesioner tersebut dibuat berdasarkan item pengukuran yang didapat dari studi literatur. Kuesioner menggunakan skala likert; h.) Penyebaran dan Pengumpulan Kuesioner Setelah kuesioner selesai dirancang, maka kuesioner akan diuji dengan meminta kurang lebih 30 responden mahasiswa untuk mengisi kuesioner dan memberikan umpan balik. Hal ini sesuai pendapat Singarimbun dan Effendi [3] yang mengatakan bahwa jumlah minimal uji coba kuesioner adalah minimal 30 responden. Dengan jumlah minimal 30 orang maka distribusi nilai akan lebih mendekati kurve normal. Jika terdapat umpan balik saat pengujian kuesioner (uji validitas dan uji reliabilitas), maka kuesioner akan diperbaiki sesuai dengan umpan balik yang diberikan. Kuesioner yang telah sesuai kemudian disebar kembali sesuai dengan ketentuan sampel dalam populasi yang telah ditentukan dalam penelitian ini; i.) Setelah uji kuesioner dinyatain memadai, maka dilakukan pengambilan data dengan menyebarkan kuesioner kepada mahasiswa di Universitas Informatika dan Bisnis Indonesia yang dijadikan responden dan dengan target sampai dengan 345 mahasiswa; j.) Pengolahan data, Kuesioner yang telah disebarkan kepada responden dan diterima kembali akan diperiksa. Jawaban yang tidak valid, seperti tidak lengkap, tidak akan diperiksa lebih lanjut. Jawaban yang valid disimpan dalam format excel, kemudian jawaban data yang diperoleh diolah dengan software AMOS 26; k.) Model akhir penelitian, dari sini kemudian diketahui hipotesishipotesis yang diterima dan ditolak. Jika terdapat dihipotesis yang ditolak dilakukan pengolahan data kembali sehingga sampai menghasilkan semua hipotesis yang diterima; 1.) Menyimpulkan seluruh penelitian yang sudah dilakukan oleh peneliti serta memberikan saran-saran berkaitan dengan dampak penelitian yang sudah dilakukan.

\section{B. Pengumpulan Data}

Pada tahap awal, penyebaran kuesioner pada penelitian kali ini diberikan langsung kepada para responden yaitu para mahasiswa di Universitas Informatika dan Bisnis Indonesia dimulai tanggal 01 sampai dengan 25 Maret 2021. Kuesioner yang ada terlebih dahulu diuji coba sebanyak dua kali dengan jumlah responden terbatas sebanyak 30 orang. Tujuannya adalah untuk melakukan uji validitas dan uji reliabilitas atas kuesioner tersebut. Setelah melakukan pengujian validitas dan reliabilitas, model penelitian akan di trimming sesuai dengan hasil pengujian untuk menghasilkan model yang lebih sederhana. Setelah itu kuesioner dari model yang telah di trimming akan kembali disebar kepada responden pada Unibi.

Skala pengukuran yang digunakan dalam kuesioner penelitian ini adalah skala likert dan skala sematic deferential. Kedua skala ini digunakan agar responden lebih mudah dalam menjawab pertanyaan kuesioner tersebut. Skala sematic deferential yang digunakan berbentuk checklist yang tersusun urut dalam satu garis mulai dari "sangat setuju" yang terletak pada sisi kanan sampai "sangat tidak setuju" pada sisi kiri. Kuesioner menggunakan google form yang dapat diakses oleh mahasiswa Unibi.

\section{Pembuatan Kuesioner}

Pembuatan pertanyaan dalam kuesioner yang digunakan di penelitian ini mengacu pada konstruk yang digunakan dalam peneltian. Selain itu pertanyaan yang digunakan juga mengacu kepada indikator yang digunakan oleh peneliti terdahulu dalam mengukur kesiapan dan penerimaan teknologi. Variabel penelitian yang digunakan sebagai acuan kuesioner adalah Perceived Usefullness, Perceived Ease of Use, Attitude Toward Using Technology, Content, Accuracy, Format, Timeliness, Ease. Tabel 2 merinci pertanyaan yang akan digunakan dalam kuesioner pada penelitian ini.

Tabel 2. Konstruk dan Pertanyaan Kuesioner Penelitian.

\begin{tabular}{|c|c|c|c|c|c|}
\hline Konstruk & Indikator & Kode & No & Kuesioner & Skala \\
\hline \multirow{2}{*}{$\begin{array}{l}\text { Perceived } \\
\text { Usefullness } \\
\text { (Persepsi } \\
\text { Kegunaan) }\end{array}$} & $\begin{array}{l}\text { Bekerja lebih } \\
\text { cepat }\end{array}$ & PU 1 & 1 & $\begin{array}{l}\text { Menurut Saya, Google } \\
\text { Classroom bermanfaat dalam } \\
\text { menunjang perkuliahan? }\end{array}$ & $\begin{array}{l}\text { Skala } \\
\text { likert }\end{array}$ \\
\hline & $\begin{array}{l}\text { Kinerja dapat } \\
\text { meningkat }\end{array}$ & PU 2 & 2 & $\begin{array}{l}\text { Menggunakan } \\
\text { Classroom }\end{array}$ & \\
\hline
\end{tabular}




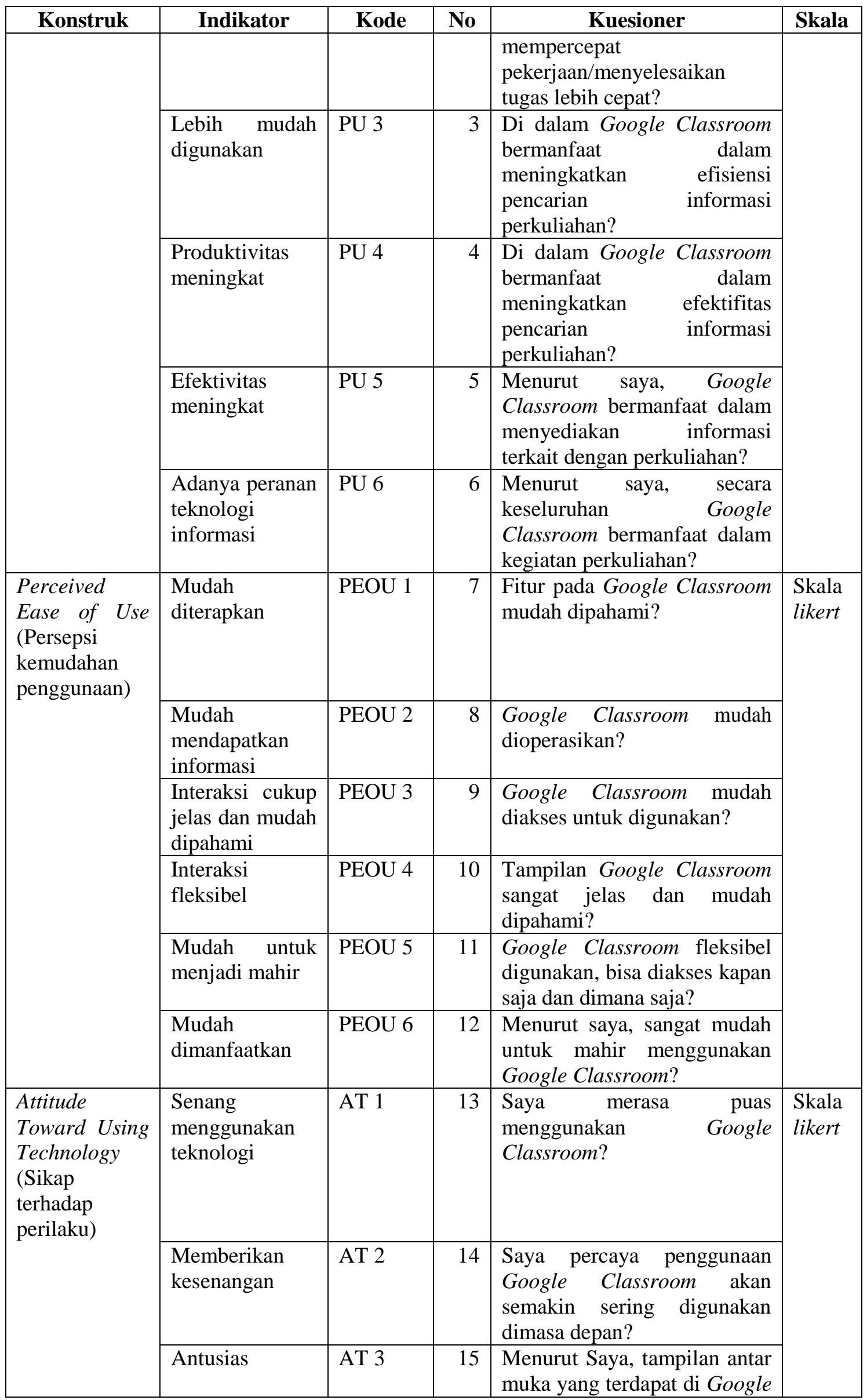




\begin{tabular}{|c|c|c|c|c|c|}
\hline Konstruk & Indikator & Kode & No & Kuesioner & Skala \\
\hline & & & & $\begin{array}{lr}\text { Classroom } & \text { tidak } \\
\text { membosankan } & \text { untuk } \\
\text { digunakan? } & \end{array}$ & \\
\hline & $\begin{array}{l}\text { Tidak pernah } \\
\text { bosan }\end{array}$ & AT 4 & 16 & $\begin{array}{l}\text { Saya senang menggunakan } \\
\text { Google Classroom? }\end{array}$ & \\
\hline \multirow[t]{5}{*}{ Content (Isi) } & Informasi tepat & CT 1 & 17 & $\begin{array}{l}\text { Google Classroom } \\
\text { menyediakan informasi yang } \\
\text { Saya butuhkan secara akurat } \\
\text { selama kegiatan perkuliahan? }\end{array}$ & \multirow[t]{5}{*}{$\begin{array}{l}\text { Skala } \\
\text { likert }\end{array}$} \\
\hline & $\begin{array}{l}\text { Isi informasi } \\
\text { memenuhi }\end{array}$ & CT 2 & 18 & $\begin{array}{l}\text { Informasi yang dihasilkan } \\
\text { oleh Google Classroom } \\
\text { membantu anda dalam } \\
\text { kegiatan perkuliahan? }\end{array}$ & \\
\hline & $\begin{array}{l}\text { Laporan sesuai } \\
\text { kebutuhan }\end{array}$ & CT 3 & 19 & $\begin{array}{l}\text { Menurut Saya, Google } \\
\text { Classroom menyediakan } \\
\text { bahan materi maupun tugas } \\
\text { sesuai dengan kebutuhan } \\
\text { perkuliahan? }\end{array}$ & \\
\hline & $\begin{array}{l}\text { Informasi yang } \\
\text { cukup }\end{array}$ & CT 4 & 20 & $\begin{array}{l}\text { Google Classroom } \\
\text { menyediakan informasi secara } \\
\text { memadai? }\end{array}$ & \\
\hline & $\begin{array}{l}\text { Adanya waktu } \\
\text { dan tanggal } \\
\text { akses website }\end{array}$ & CT 5 & 21 & $\begin{array}{l}\text { Dalam menggunakan Google } \\
\text { Classroom terdapat waktu } \\
\text { dan tanggal akses website } \\
\text { setiap user (pengguna)? }\end{array}$ & \\
\hline \multirow[t]{5}{*}{$\begin{array}{l}\text { Accuracy } \\
\text { (Keakuatan) }\end{array}$} & $\begin{array}{l}\text { Informasi yang } \\
\text { dihasilkan } \\
\text { akurat }\end{array}$ & $\mathrm{AC} 1$ & 22 & $\begin{array}{l}\text { Menurut Saya, Google } \\
\text { Classroom memberikan hasil } \\
\text { informasi yang akurat? }\end{array}$ & \multirow[t]{5}{*}{$\begin{array}{l}\text { Skala } \\
\text { likert }\end{array}$} \\
\hline & $\begin{array}{l}\text { Puas dengan } \\
\text { akurasi sistem }\end{array}$ & AC 2 & 23 & $\begin{array}{lr}\text { Keakuratan } & \text { Google } \\
\text { Classroom memberikan } \\
\text { kepuasan untuk Saya? }\end{array}$ & \\
\hline & $\begin{array}{lr}\text { Jarang } & \text { terjadi } \\
\text { error } & \text { pada } \\
\text { sistem } & \\
\end{array}$ & AC 3 & 24 & $\begin{array}{lrr}\text { Menurut } & \text { saya, } & \text { jarang } \\
\text { terjadinya } & \text { error } & \text { saat } \\
\text { menggunakan } & \text { Google } \\
\text { Classroom? } & & \end{array}$ & \\
\hline & 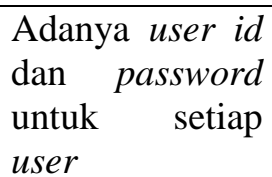 & $\mathrm{AC} 4$ & 25 & $\begin{array}{l}\text { Adakah user id dan password } \\
\text { saat menggunakan Google } \\
\text { Classroom? }\end{array}$ & \\
\hline & $\begin{array}{l}\text { Adanya } \\
\text { keterangan } \\
\text { tahapan dan } \\
\text { waktu proses }\end{array}$ & AC 5 & 26 & $\begin{array}{l}\text { Adakah keterangan tahapan } \\
\text { dan waktu proses di dalam } \\
\text { Google Classroom? }\end{array}$ & \\
\hline \multirow[t]{3}{*}{$\begin{array}{l}\text { Format } \\
\text { (Tampilan) }\end{array}$} & $\begin{array}{l}\text { Penyajian } \\
\text { output/laporan }\end{array}$ & FT 1 & 27 & $\begin{array}{l}\text { Output (hasil akhir) yang } \\
\text { ditampilkan pada Google } \\
\text { Classroom sangat berguna } \\
\text { untuk Saya? }\end{array}$ & \multirow[t]{3}{*}{$\begin{array}{l}\text { Skala } \\
\text { likert }\end{array}$} \\
\hline & Informasi jelas & FT 2 & 28 & $\begin{array}{l}\text { Informasi yang ada di Google } \\
\text { Classroom menurut Saya } \\
\text { sangat jelas? }\end{array}$ & \\
\hline & $\begin{array}{l}\text { Konsistensi } \\
\begin{array}{l}\text { layout } \\
\text { tahapan) }\end{array}\end{array}$ & FT 3 & 29 & $\begin{array}{l}\text { Menurut saya, Google } \\
\text { Classroom memiliki tampilan } \\
\text { ukuran huruf yang normal }\end{array}$ & \\
\hline
\end{tabular}




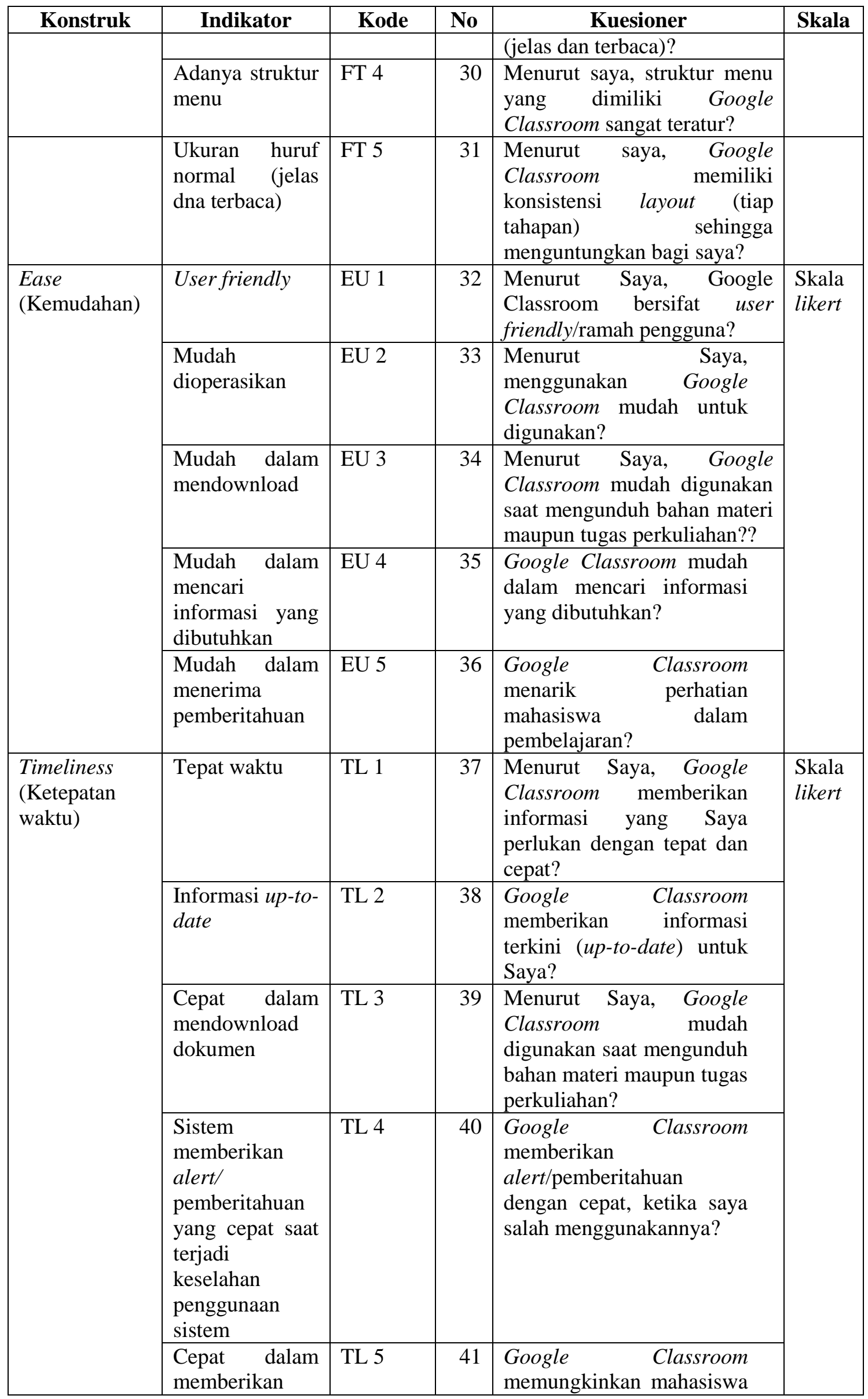




\begin{tabular}{|l|l|l|l|l|c|}
\hline Konstruk & \multicolumn{1}{|c|}{ Indikator } & Kode & No & \multicolumn{1}{|c|}{ Kuesioner } & Skala \\
\hline & $\begin{array}{l}\text { tanggapan } \\
\text { keluhan }\end{array}$ & & & $\begin{array}{l}\text { mendapatkan umpan balik } \\
\text { secara lebih cepat? }\end{array}$ & \\
\hline
\end{tabular}
berikut:

Adapun skala likert yang digunakan dalam penelitian seperti dirinci pada tabel 3 sebagai

\begin{tabular}{|l|l|l|l|}
\hline \multicolumn{3}{|c|}{ Tabel 3. Skala likert } \\
\hline Skala & Jawaban & \multicolumn{1}{|c|}{ Deskripsi } & \multicolumn{1}{c|}{ Keterangan } \\
\hline 1 & STS & Sangat Tidak Setuju & $\begin{array}{l}\text { Jawaban jika responden Sangat Tidak } \\
\text { Setuju (STS) dengan pertanyaan yang } \\
\text { tertulis berdasarkan pendapat dari } \\
\text { responden atau keadaan yang terjadi }\end{array}$ \\
\hline 3 & TS & Tidak Setuju & $\begin{array}{l}\text { Jawaban jika responden Tidak Setuju } \\
\text { (TS) dengan pertanyaan yang tertulis } \\
\text { berdasarkan pendapat dari responden } \\
\text { atau keadaan yang terjadi }\end{array}$ \\
\hline 4 & N & Netral & $\begin{array}{l}\text { Jawaban jika responden Netral (N) } \\
\text { dengan pertanyaan yang tertulis } \\
\text { berdasarkan pendapat dari responden } \\
\text { ataukeadaan yang terjadi }\end{array}$ \\
\hline 5 & SS & Setuju & $\begin{array}{l}\text { Jawaban jika responden Setuju (S) } \\
\text { dengan pertanyaan yang tertulis } \\
\text { berdasarkan pendapat dari responden } \\
\text { ataukeadaan yang terjadi }\end{array}$ \\
\hline
\end{tabular}

\section{Analisis Responden}

Total responden penelitian ini adalah 373 responden yang meliputi mahasiswa di Unibi. Data profil seluruh responden dapat dilihat pada tabel 4

Tabel 4. Data Profil Responden

\begin{tabular}{|l|l|r|r|}
\hline $\begin{array}{c}\text { Data Responden } \\
\text { berdasarkan }\end{array}$ & \multicolumn{1}{|c|}{ Kategori } & \multicolumn{1}{|c|}{$\begin{array}{c}\text { Jumlah } \\
\text { Responden }\end{array}$} & \multicolumn{1}{|c|}{ Presentase } \\
\hline \multirow{3}{*}{ Jenis Kelamin } & Laki- laki & 157 mahasiswa & $42 \%$ \\
\cline { 2 - 4 } & Perempuan & 216 mahasiswa & $58 \%$ \\
\hline \multirow{4}{*}{ Program Studi } & Akuntansi & 26 mahasiswa & $7 \%$ \\
\cline { 2 - 4 } & DKV & 8 mahasiswa & $4 \%$ \\
\cline { 2 - 4 } & Ilmu Komunikasi & 16 mahasiswa & $9 \%$ \\
\cline { 2 - 4 } & Manajemen & 33 mahasiswa & $10 \%$ \\
\cline { 2 - 4 } & Sistem Informasi & 38 mahasiswa & $10 \%$ \\
\cline { 2 - 4 } & Informatika & 39 mahasiswa & \\
\hline
\end{tabular}




\section{Jenis Kelamin}

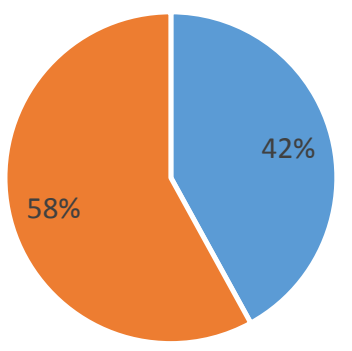

- Laki - laki - Perempuan

\section{Gambar 5. Diagram Profil Responden berdasarkan Jenis Kelamin}

Berdasarkan profil responden berdasarkan jenis kelamin, responden laki - laki lebih sedikit dibanding responden perempuan. Responden dengan jenis kelamin laki - laki (42\%) dan jenis kelamin perempuan $(58 \%)$.

\section{Program Studi}

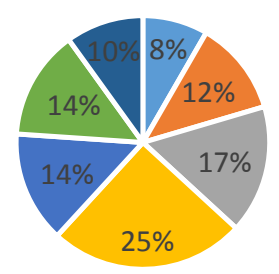

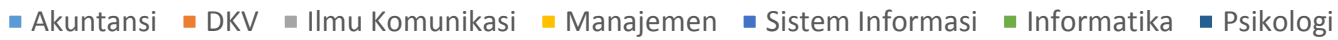

\section{Gambar 6. Diagram Profil Responden berdasarkan Fakultas}

Berdasarkan profil responden berdasarkan program studi, dengan rincian responden pada program studi Akuntasi, Manajemen, Psikologi, DKV, Informatika, Sistem Informasi dan Ilmu Komunikasi.

\section{E. Pengujian Validitas Keseluruhan}

Tabel 5. Pengujian Validitas Keseluruhan

\begin{tabular}{|l|l|r|l|l|l|r|l|}
\hline No & Manifes & $\begin{array}{c}\text { Nilai } \\
\text { Output }\end{array}$ & Status & No & Manifes & $\begin{array}{c}\text { Nilai } \\
\text { Output }\end{array}$ & Status \\
\hline 1 & PU 1 & 0,477 & Valid & 26 & AC 5 & 0,755 & Valid \\
\hline 2 & PU 2 & 0,668 & Valid & 27 & FT 1 & 0,783 & Valid \\
\hline 3 & PU 3 & 0,849 & Valid & 28 & FT 2 & 0,888 & Valid \\
\hline 4 & PU 4 & 0,898 & Valid & 29 & FT 3 & 0,854 & Valid \\
\hline 5 & PU 5 & 0,697 & Valid & 30 & FT 4 & 0,851 & Valid \\
\hline 6 & PU 6 & 0,877 & Valid & 31 & FT 5 & 0,822 & Valid \\
\hline 7 & PEOU 1 & 0,193 & Tidak & 32 & EU 1 & 0,894 & Valid \\
\hline 8 & PEOU 2 & 0,796 & Valid & 33 & EU 2 & 0,922 & Valid \\
\hline 9 & PEOU 3 & 0,813 & Valid & 34 & EU 3 & 0,799 & Valid \\
\hline 10 & PEOU 4 & 0,825 & Valid & 35 & EU 4 & 0,736 & Valid \\
\hline 11 & PEOU 5 & 0,721 & Valid & 36 & EU 5 & 0,745 & Valid \\
\hline 12 & PEOU 6 & 0,921 & Valid & 37 & TL 1 & 0,836 & Valid \\
\hline
\end{tabular}




\begin{tabular}{|c|c|c|c|c|c|c|c|}
\hline No & Manifes & $\begin{array}{l}\text { Nilai } \\
\text { Output }\end{array}$ & Status & No & Manifes & $\begin{array}{l}\text { Nilai } \\
\text { Output }\end{array}$ & Status \\
\hline 13 & AT 1 & 0,753 & Valid & 38 & TL 2 & 0,860 & Valid \\
\hline 14 & AT 2 & 0,875 & Valid & 39 & TL 3 & 0,751 & Valid \\
\hline 15 & AT 3 & 0,839 & Valid & 40 & TL 4 & 0,868 & Valid \\
\hline 16 & AT 4 & 0,847 & Valid & 41 & TL 5 & 0,774 & Valid \\
\hline 17 & CT 1 & 0,894 & Valid & & & & \\
\hline 18 & CT 2 & 0,922 & Valid & & & & \\
\hline 19 & CT 3 & 0,799 & Valid & & & & \\
\hline 20 & CT 4 & 0,736 & Valid & & & & \\
\hline 21 & CT 5 & 0,745 & Valid & & & & \\
\hline 22 & AC 1 & 0,737 & Valid & & & & \\
\hline 23 & $\mathrm{AC} 2$ & 0,823 & Valid & & & & \\
\hline 24 & $\mathrm{AC} 3$ & 0,887 & Valid & & & & \\
\hline 25 & AC 4 & 0,667 & Valid & & & & \\
\hline
\end{tabular}

Pada tabel 5. terdapat 41 indikator dari semua konstruk yang digunakan dapat diberikan kesimpulan valid karena nilai korelasi (pearson correlation) adalah positif dan $r$ Hitung lebih besar dari $\mathrm{r}$ Tabel. Namun terdapat 1 indikator yang tidak memenuhi persyaratan, maka 40 indikator yang telah dinyatakan valid.

\section{F. Uji Reliabilitas}

Reliabilitas menunjuk pada suatu pengertian bahwa sesuatu cukup dapat dipercaya untuk digunakan sebagai alat pengumpul data karena instrument tersebut sudah baik. Angket dikatakan reliabel jika dapat memberikan hasil relatif sama pada saat dilakukan pengukuran kembali pada obyek yang berlainan pada waktu yang berbeda atau memberikan hasil yang tetap. Suatu instrumen dapat dikatakan reliabel apabila memiliki nilai Cronbach Alpha lebih besar dari 0,600.

\section{Case Processing Summary}

\begin{tabular}{ccc|c} 
& & $\mathrm{N}$ & $\%$ \\
\hline \multirow{3}{*}{ Cases } & Valid & 30 & 100.0 \\
\cline { 2 - 4 } & Excluded $^{\mathrm{a}}$ & 0 & .0 \\
\cline { 2 - 4 } & Total & 30 & 100.0 \\
\hline
\end{tabular}

a. Listwise deletion based on all variables in the procedure.

\section{Reliability Statistics}

\begin{tabular}{c|c}
$\begin{array}{c}\text { Cronbach's } \\
\text { Alpha }\end{array}$ & N of Items \\
\hline .968 & 41 \\
\hline
\end{tabular}

\section{Gambar 7. Nilai Cronbach's Alpha Kuesioner}

Kuesioner dinyatakan reliabel apabila nilai Cronbach's Alpha yang didapat lebih besar dari 0,600, nilai Cronbach's Alpha yang didapat adalah 0,964 maka kuesioner ini dapat dinyatakan reliabel.

\section{G. Pengujian Ulang}

Setelah menghilangkan item - item yang tidak valid maka pengujian yang menghasilkan tabel validitas item kuesioner seperti pada tabel 6.

Tabel 6. Pengujian Ulang

\begin{tabular}{|c|l|r|r|l|}
\hline No & $\begin{array}{c}\text { Korelasi item } \\
\text { dengan total }\end{array}$ & r Hitung & $\begin{array}{c}\text { r Tabel } \\
\text { df }=\mathbf{3 7 1} \boldsymbol{\alpha}=\mathbf{0 . 0 5}\end{array}$ & Kesimpulan \\
\hline 1 & PU 1 & 0,237 & & Valid \\
\cline { 2 - 3 } & PU 2 & 0,758 & & Valid \\
\cline { 1 - 2 } & & &
\end{tabular}




\begin{tabular}{|c|c|c|c|c|}
\hline No & $\begin{array}{c}\text { Korelasi item } \\
\text { dengan total }\end{array}$ & r Hitung & $\begin{array}{c}\text { r Tabel } \\
\text { df }=\mathbf{3 7 1} \alpha=\mathbf{0 . 0 5}\end{array}$ & Kesimpulan \\
\hline 3 & PU 3 & 0,801 & \multirow{38}{*}{0,113} & Valid \\
\hline 4 & PU 4 & 0,845 & & Valid \\
\hline 5 & PU 5 & 0,694 & & Valid \\
\hline 6 & PU 6 & 0,783 & & Valid \\
\hline 7 & PEOU 2 & 0,840 & & Valid \\
\hline 8 & PEOU 3 & 0,841 & & Valid \\
\hline 9 & PEOU 4 & 0,849 & & Valid \\
\hline 10 & PEOU 5 & 0,750 & & Valid \\
\hline 11 & PEOU 6 & 0,748 & & Valid \\
\hline 12 & AT 1 & 0,751 & & Valid \\
\hline 13 & AT 2 & 0,780 & & Valid \\
\hline 14 & AT 3 & 0,784 & & Valid \\
\hline 15 & AT 4 & 0,813 & & Valid \\
\hline 16 & CT 1 & 0,794 & & Valid \\
\hline 17 & CT 2 & 0,794 & & Valid \\
\hline 18 & CT 3 & 0,789 & & Valid \\
\hline 19 & CT 4 & 0,787 & & Valid \\
\hline 20 & CT 5 & 0,759 & & Valid \\
\hline 21 & $\mathrm{AC} 1$ & 0,813 & & Valid \\
\hline 22 & AC 2 & 0,817 & & Valid \\
\hline 23 & $\mathrm{AC} 3$ & 0,735 & & Valid \\
\hline 24 & $\mathrm{AC} 4$ & 0,647 & & Valid \\
\hline 25 & AC 5 & 0,781 & & Valid \\
\hline 26 & FT 1 & 0,826 & & Valid \\
\hline 27 & FT 2 & 0,847 & & Valid \\
\hline 28 & FT 3 & 0,791 & & Valid \\
\hline 29 & FT 4 & 0,759 & & Valid \\
\hline 30 & FT 5 & 0,810 & & Valid \\
\hline 31 & EU 1 & 0,699 & & Valid \\
\hline 32 & EU 2 & 0,877 & & Valid \\
\hline 33 & EU 3 & 0,826 & & Valid \\
\hline 34 & EU 4 & 0,848 & & Valid \\
\hline 35 & EU 5 & 0,797 & & Valid \\
\hline 36 & TL 1 & 0,806 & & Valid \\
\hline 37 & TL 2 & 0,833 & & Valid \\
\hline 38 & TL 3 & 0,822 & & Valid \\
\hline 39 & TL 4 & 0,868 & & Valid \\
\hline 40 & TL 5 & 0,820 & & Valid \\
\hline
\end{tabular}

Model pengujian validitas ini menggunakan rumus korelasi biverate pearson untuk menguji validitas internal setiap item pertanyaan dalam kuesioner. Hasil pengujian ulang dengan SPSS 26 menunjukkan bahwa semua item pertanyaan memiliki nilai $r$ Hitung lebih besar dari $r$ Tabel yang memiliki arti lebih besar dari 0,113. Maka dari itu dapat disimpulkan bahwa pada pengujian hasil ulang secara keseluruhan item dalam kuesioner adalah valid. Pengujian ini juga mengubah $\mathrm{N}$ reliabilitas kuesioner dari 0,968 menjadi 0,959 yang tetap masih diatas 0,600 sehingga masih dinyatakan reliabel.

Case Processing Summary 


\begin{tabular}{llr|r}
\hline Cases & Valid & 373 & 100.0 \\
\cline { 2 - 4 } & Excluded $^{\mathrm{a}}$ & 0 & .0 \\
\cline { 2 - 4 } & Total & 373 & 100.0 \\
\hline
\end{tabular}

a. Listwise deletion based on all variables in the procedure.

\section{Reliability Statistics \\ Cronbach's

\begin{tabular}{r|r} 
Alpha & N of Items \\
\hline .959 & 40 \\
\hline
\end{tabular} \\ Gambar 8. Nilai Cronbach's Alpha Kuesioner Ulang}

\section{Hasil dan Pembahasan}

\section{A. Operasional Variabel}

Setelah melakukan uji validitas dan reliabilitas, diperoleh hasil bahwa model penelitian ini reliabel dan manifes penelitian. Gambar 9 merupakan model penelitian digambarkan menggunakan software AMOS 26.

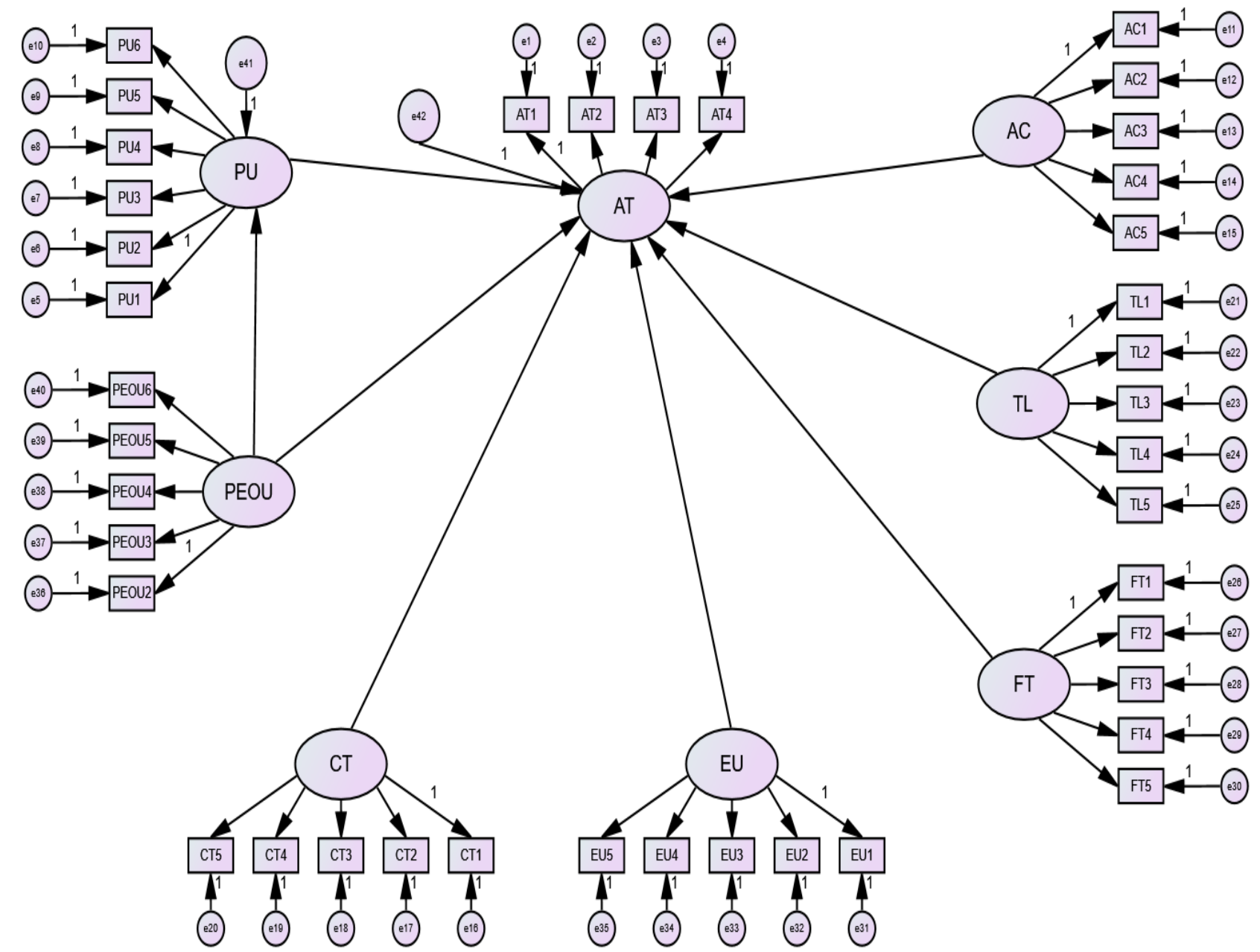

Gambar 9. Operasional Variabel

\section{B. Pengujian Operasional Variabel}

\section{Pengujian Tahap Pertama}

Model penelitian ini terdiri atas sembilan konstruk dan empat puluh empat manifes, yaitu konstruk persepsi kegunaan dengan enam buah manifes, konstruk persepsi kemudahan penggunaan dengan lima buah manifes, konstruk sikap terhadap perilaku dengan empat buah manifes, konstruk isi 
dengan lima buah manifes, konstruk keakuratan dengan lima buah manifes, konstruk tampilan dengan lima buah manifes, konstruk kemudahan dengan lima buah manifes, konstruk ketepatan waktu dengan lima buah manifes dan konstruk persepsi keunggulan relatif dengan empat buah manifest. Pada tahap pertama, model yang dihipotesiskan menghasilkan parameter seperti digambarkan seperti berikut ini.

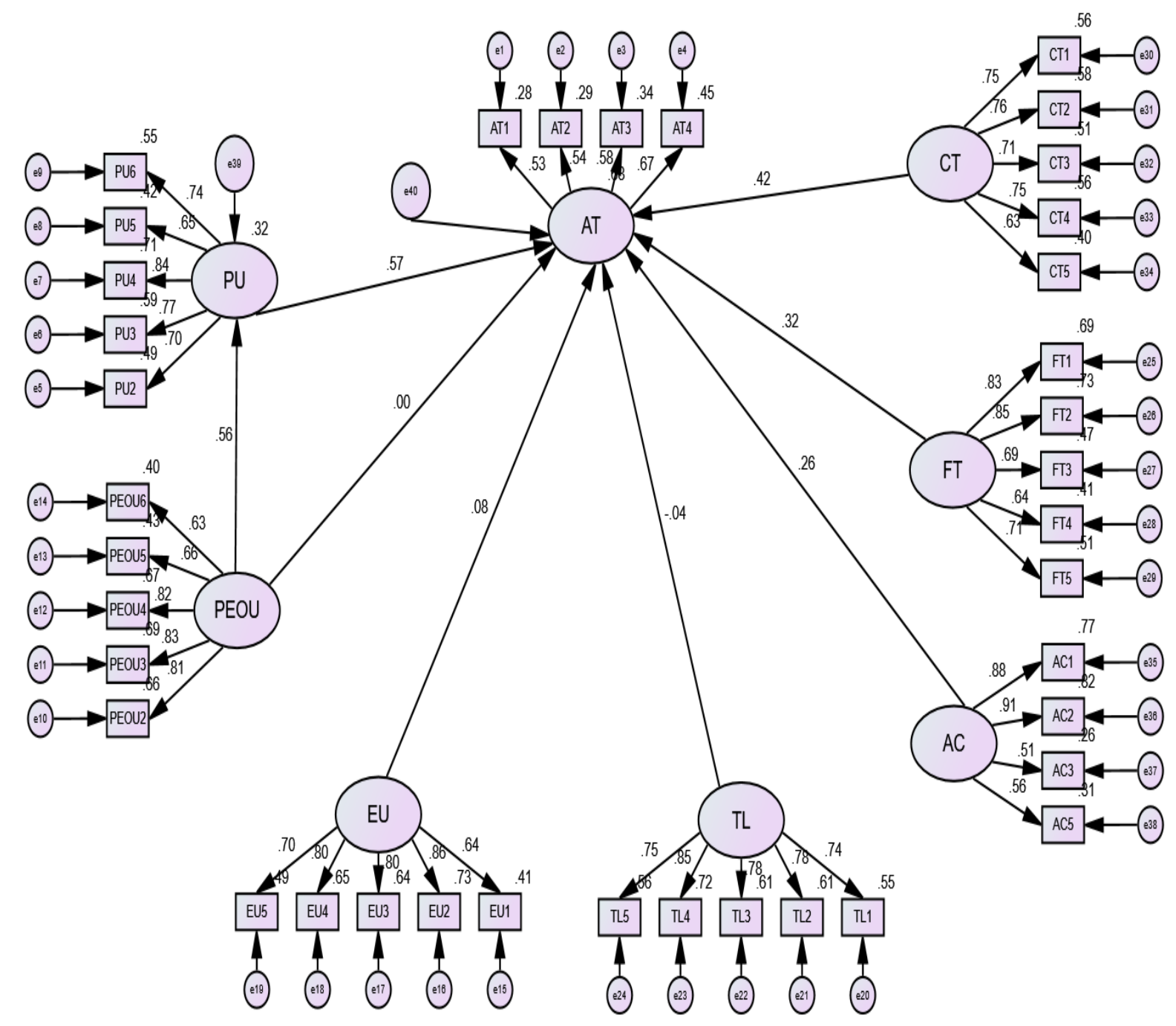

Gambar 10. Hasil Pengujian Tahap Pertama

\section{Uji Validitas (Convergen Validity) Tahap Pertama}

Uji Validitas (convergent validity) digunakan untuk menguji apakah sebuah indikator adalah bagian dari sebuah konstruk. Uji validitas bisa dilihat dari nilai standardized regression weight. Hasil uji convergent validity untuk penelitian ini ditampilkan sebagai berikut. Berdasarkan tabel 7 , seluruh indikator berhubungan dari konstruknya dan signifikan secara statistik. Sehingga seluruh indikator memang merupakan bagian dari konstruknya. Untuk melengkapi, berikut disertakan tampilan estimate yang sudah distandarisasi.

\section{Tabel 7. Standardized regression weights Tahap Pertama}

\begin{tabular}{|lll|r|}
\hline & & & Estimate \\
\hline AT1 & $<---$ & AT & .529 \\
AT2 & $<---$ & AT & .537 \\
AT3 & $<---$ & AT & .580 \\
AT4 & $<---$ & AT & .667 \\
PU1 & $<---$ & PU & .034 \\
PU2 & $<---$ & PU & .697 \\
\hline
\end{tabular}




\begin{tabular}{|c|c|c|c|}
\hline & & & Estimate \\
\hline PU3 & $<--$ & PU & .765 \\
\hline PU4 & $<--$ & PU & .842 \\
\hline PU5 & $<--$ & PU & .645 \\
\hline PU6 & $<--$ & PU & .742 \\
\hline AC1 & $<--$ & $\mathrm{AC}$ & .884 \\
\hline $\mathrm{AC} 2$ & $<--$ & $\mathrm{AC}$ & .892 \\
\hline AC3 & $<--$ & $\mathrm{AC}$ & .522 \\
\hline AC4 & $<--$ & $\mathrm{AC}$ & .444 \\
\hline AC5 & $<--$ & $\mathrm{AC}$ & .587 \\
\hline CT1 & $<--$ & CT & .747 \\
\hline $\mathrm{CT} 2$ & $<--$ & CT & .762 \\
\hline CT3 & $<--$ & CT & .712 \\
\hline CT4 & $<--$ & CT & .750 \\
\hline CT5 & $<--$ & CT & .630 \\
\hline TL1 & $<--$ & $\mathrm{TL}$ & .742 \\
\hline TL2 & $<--$ & TL & .782 \\
\hline TL3 & $<--$ & TL & .784 \\
\hline TL4 & $<--$ & TL & .851 \\
\hline TL5 & $<--$ & $\mathrm{TL}$ & .750 \\
\hline FT1 & $<--$ & FT & .830 \\
\hline FT2 & $<--$ & FT & .853 \\
\hline FT3 & $<--$ & FT & .685 \\
\hline FT4 & $<--$ & FT & .638 \\
\hline FT5 & $<--$ & FT & .713 \\
\hline EU1 & $<--$ & EU & .638 \\
\hline EU2 & $<--$ & EU & .855 \\
\hline EU3 & $<--$ & EU & .800 \\
\hline EU4 & $<--$ & $\mathrm{EU}$ & .804 \\
\hline EU5 & $<--$ & EU & .698 \\
\hline PEOU2 & $<--$ & PEOU & .814 \\
\hline PEOU3 & $<--$ & PEOU & .829 \\
\hline PEOU4 & $<--$ & PEOU & .819 \\
\hline PEOU5 & $<--$ & PEOU & .655 \\
\hline PEOU6 & $<--$ & PEOU & .633 \\
\hline
\end{tabular}

Factor Loading yang bernilai $>0,5$ menunjukkan bahwa sebuah indikator memang bagian dari konstruk (Santoso, 2014). Dari hasil tabel diatas, maka indikator yang mempunyai loading factor dibawah 0,5 berarti tidak valid, karena tidak sesuai syarat convergent validity. Sehingga indikator yang harus dibuang pada model adalah PU1 dan AC4.

\section{Uji Model Tahap Pertama}

Pengujian konstruk dan model penelitian dilakukan menggunakan SPSS AMOS 26. Gambar 7 merupakan model penelitian yang dibuat menggunakan AMOS. Gambar 8 merupakan hasil uji model tahap pertama setalah indikator dihilangkan. 


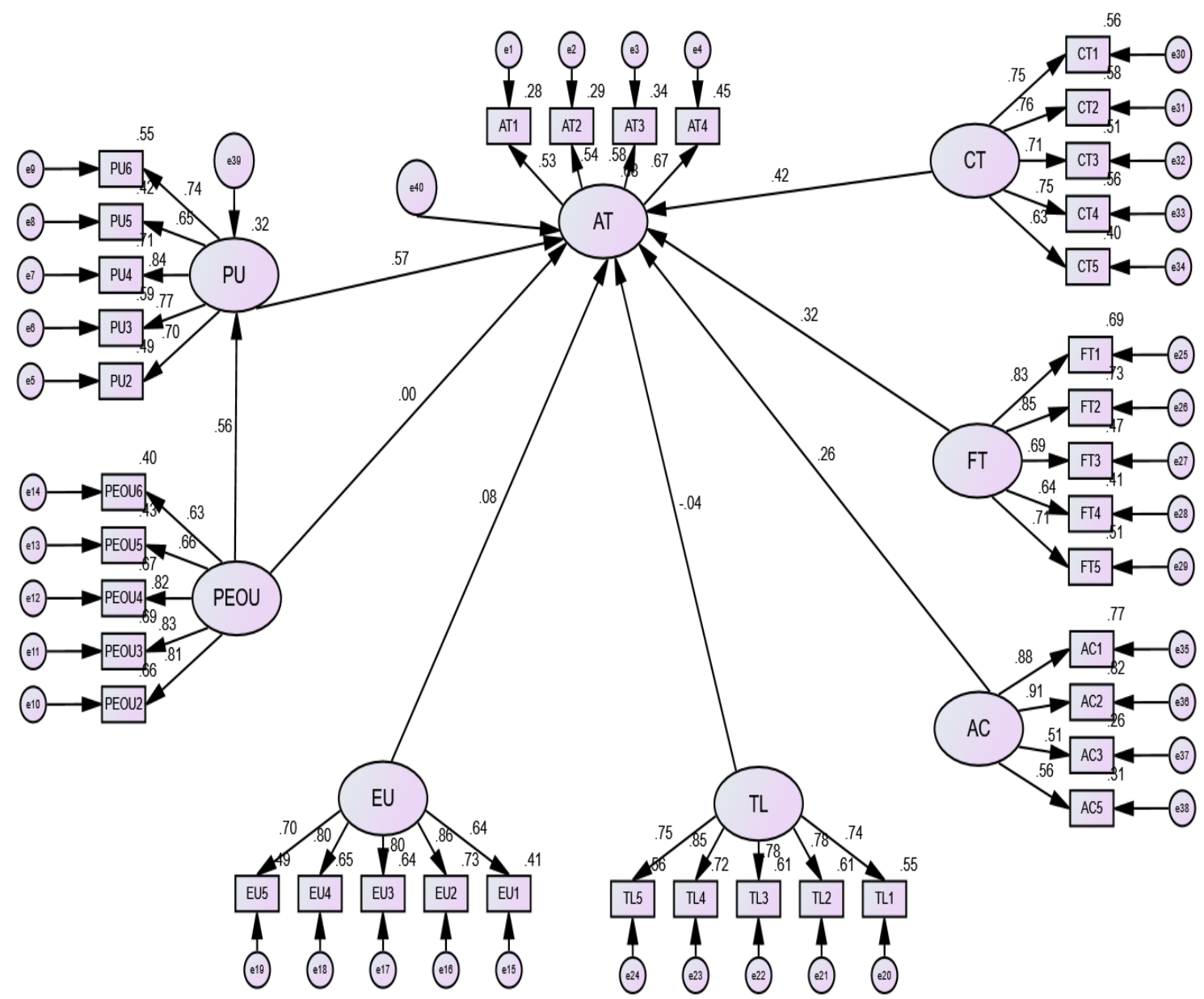

Gambar 11. Hasil Pengujian Tahap Pertama

Hasil pengujian model struktural menggunakan SPSS AMOS 26 menghasilkan tingkat kesesuaian seperti pada tabel 8 .

Tabel 8. Hasil Uji Model Tahap Pertama

\begin{tabular}{|l|r|l|l|}
\hline \multicolumn{1}{|c|}{ Kriteria Model Fit } & \multicolumn{1}{c|}{$\begin{array}{c}\text { Hasil } \\
\text { Uji }\end{array}$} & \multicolumn{1}{|c|}{ Acceptable Level } & \multicolumn{1}{|c|}{ Interpretasi } \\
\hline CMIN (Chi Square) & 3890.173 & $\begin{array}{l}\text { Diantara Saturated dan } \\
\text { Independence Model }\end{array}$ & Kesesuaian Baik \\
\hline GFI (Goodness of Fit Index) & 0.566 & 0 (tidak fit) s/d 1 (Fit) & Kesesuaian Menengah \\
\hline AGFI (Adjustes GFI) & 0.511 & 0 (tidak fit) s/d 1 (Fit) & Kesesuaian Menengah \\
\hline $\begin{array}{l}\text { RMSEA (Root mean square } \\
\text { error of approximation) }\end{array}$ & 0.115 & $<0.080$ (Fit) & Kesesuaian Rendah \\
\hline $\begin{array}{l}\text { TLI (Tucker-Lewis Index) } \\
\text { NFI (Normed Fit Index) }\end{array}$ & 0.641 & 0 (tidak fit) s/d 1 (Fit) & Kesesuaian Menengah \\
\hline CFI (Confirmatory Fit Index) & 0.623 & 0 (tidak fit) s/d 1 (Fit) & Kesesuaian Menengah \\
\hline PNFI (Parcimonious Fit Index) & 0.583 & $>0.600$ (Fit) & Kesesuaian Rendah \\
\hline
\end{tabular}


Dari tabel 8 dapat terlihat bahwa model tahap pertama memiliki kesesuaian menengah hanya nilai RMSEA yang tidak memenuhi kriteria.

\section{Pengujian Tahap Kedua}

Dari hasil pengujian tahap pertama tersebut, masih terdapat data-data yang mengandung outlier dalam mengukur konstruknya dan indikator PU1 dan AC4 sehingga mempengaruh goodness of fit dari model yang dihipotesiskan. Dalam tahap kedua ini, dilakukan pengulangan pengujian kembali setelah outlier dan indikator PU1 dan AC4 dihapus. Berikut hasil pengujian tahap kedua atau model setelah direvisi:

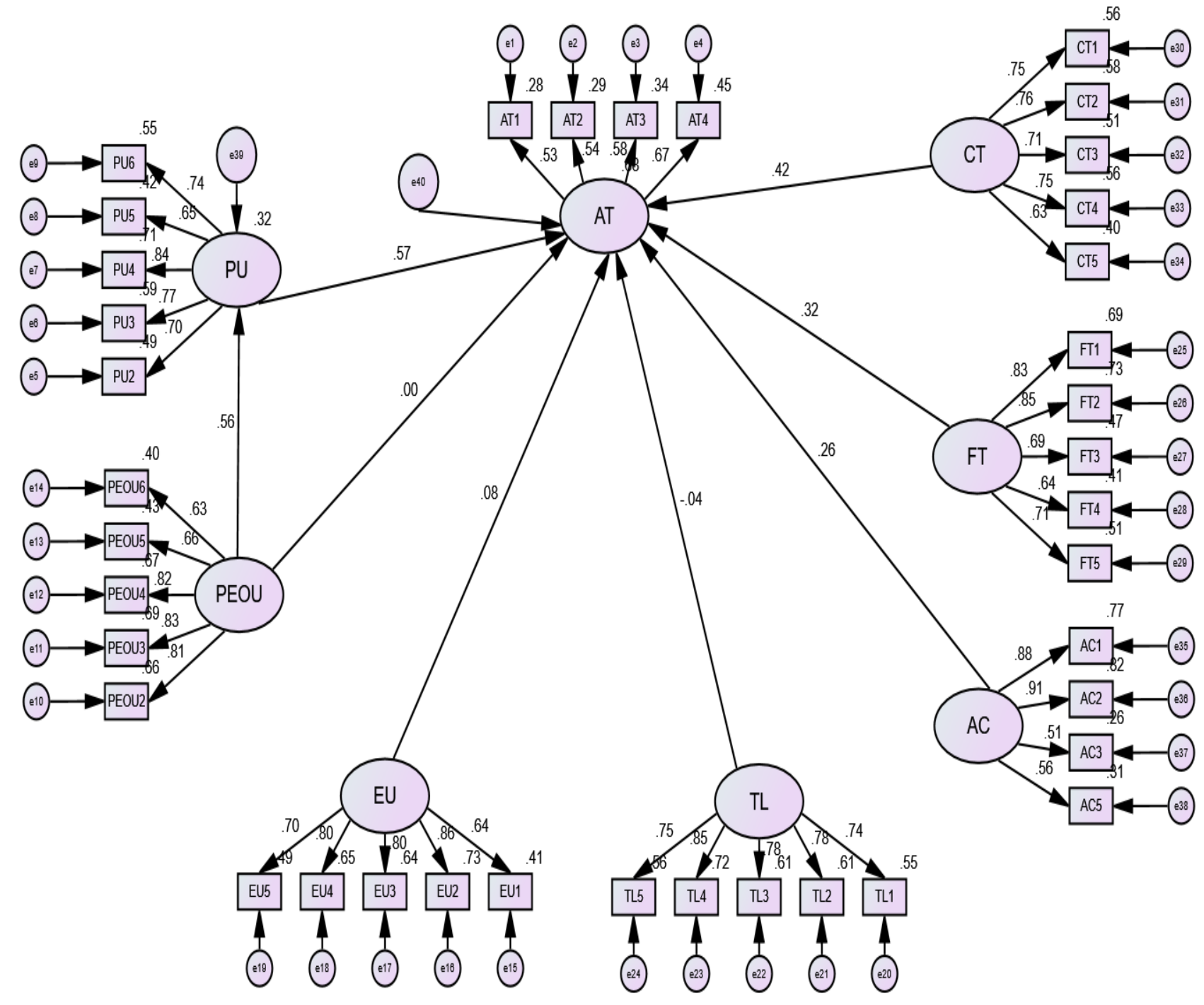

Gambar 12. Model Pengujian Tahap Kedua

\section{Uji Validitas (Convergen Validity) Tahap Kedua}

Berdasarkan tabel 9, seluruh indikator berhubungan dari konstruknya dan signifikan secara statistik. Sehingga seluruh indikator memang merupakan bagian dari konstruknya. Untuk melengkapi, berikut disertakan tampilan estimate yang sudah distandarisasi. 
Tabel 9. Standardized regression weights Tahap Kedua

\begin{tabular}{|c|c|c|c|}
\hline & & & Estimate \\
\hline AT1 & $<--$ & AT & .528 \\
\hline AT2 & $<---$ & AT & .537 \\
\hline AT3 & $<---$ & AT & .580 \\
\hline AT4 & $<---$ & AT & .667 \\
\hline PU2 & $<---$ & PU & .697 \\
\hline PU3 & $<---$ & PU & .765 \\
\hline PU4 & $<---$ & PU & .842 \\
\hline PU5 & $<--$ & PU & .645 \\
\hline PU6 & $<---$ & PU & .742 \\
\hline PEOU2 & $<--$ & PEOU & .814 \\
\hline PEOU3 & $<--$ & PEOU & .829 \\
\hline PEOU4 & $<--$ & PEOU & .819 \\
\hline PEOU5 & $<--$ & PEOU & .655 \\
\hline PEOU6 & $<--$ & PEOU & .633 \\
\hline EU1 & $<--$ & EU & .638 \\
\hline EU2 & $<---$ & EU & .855 \\
\hline EU3 & $<---$ & EU & .801 \\
\hline EU4 & $<---$ & EU & .804 \\
\hline EU5 & $<---$ & EU & .698 \\
\hline TL1 & $<--$ & TL & .742 \\
\hline TL2 & $<---$ & $\mathrm{TL}$ & .782 \\
\hline TL3 & $<---$ & TL & .784 \\
\hline TL4 & $<---$ & $\mathrm{TL}$ & .851 \\
\hline TL5 & $<---$ & TL & .750 \\
\hline FT1 & $<---$ & FT & .830 \\
\hline FT2 & $<---$ & FT & .853 \\
\hline FT3 & $<---$ & FT & .685 \\
\hline FT4 & $<---$ & FT & .639 \\
\hline FT5 & $<---$ & FT & .713 \\
\hline CT1 & $<---$ & $\mathrm{CT}$ & .747 \\
\hline CT2 & $<---$ & $\mathrm{CT}$ & .762 \\
\hline CT3 & $<--$ & $\mathrm{CT}$ & .712 \\
\hline CT4 & $<---$ & $\mathrm{CT}$ & .750 \\
\hline CT5 & $<---$ & $\mathrm{CT}$ & .630 \\
\hline $\mathrm{AC} 1$ & $<---$ & $\mathrm{AC}$ & .880 \\
\hline $\mathrm{AC} 2$ & $<---$ & $\mathrm{AC}$ & .907 \\
\hline AC3 & $<--$ & $\mathrm{AC}$ & .514 \\
\hline AC5 & $<---$ & $\mathrm{AC}$ & .561 \\
\hline
\end{tabular}

Factor Loading yang bernilai > 0,5 menunjukkan bahwa sebuah indikator memang bagian dari konstruk (Santoso, 2014). Dari hasil tabel diatas, maka indikator yang mempunyai loading factor dibawah 0,5 berarti tidak valid, karena tidak sesuai syarat convergent validity.

\section{Pengujian Hipotesis dengan SEM}

Pengujian hipotesis penelitian berdasarkan pada model penelitian yang dikembangkan, pengujian ini dilakukan untuk melihat hubungan diantara konstruk - konstruk yang ada dalam model penelitian. Daftar pengambilan keputusan diambil dengan melihat bobot regresi untuk konstruk terkait pada hasil pengujian menggunakan SPSS AMOS 26. Jika nilai $\mathrm{P}>0.05$ maka $\mathrm{H} 0$ ditolak dan apabila nilai $\mathrm{P}<$ 0.05 atau dilambangkan dengan $* * *$ maka $\mathrm{H} 1$ diterima seperti dipaparkan pada tabel 6. 
Tabel 10. Hasil Nilai Regression Weights Model Penelitian

\begin{tabular}{|c|c|c|c|c|c|}
\hline & Estimate & S.E. & C.R. & $\mathbf{P}$ & Label \\
\hline PU <--- & .522 & .059 & 8.911 & $* * *$ & par_33 \\
\hline AT <--- & .347 & .056 & 6.198 & **** & par_31 \\
\hline AT <--- & .001 & .044 & .025 & 980 & par_32 \\
\hline$<---$ & 057 & .071 & .806 & .420 & par_34 \\
\hline AT <--- & -.025 & .057 & -.438 & .661 & par_35 \\
\hline AT <--- AC & .128 & .039 & 3.262 & .001 & par_36 \\
\hline AT <--- & 169 & .051 & 3.301 & $* * *$ & par_37 \\
\hline AT $<---\quad$ CT & .259 & .060 & 4.309 & $* * *$ & par_38 \\
\hline
\end{tabular}

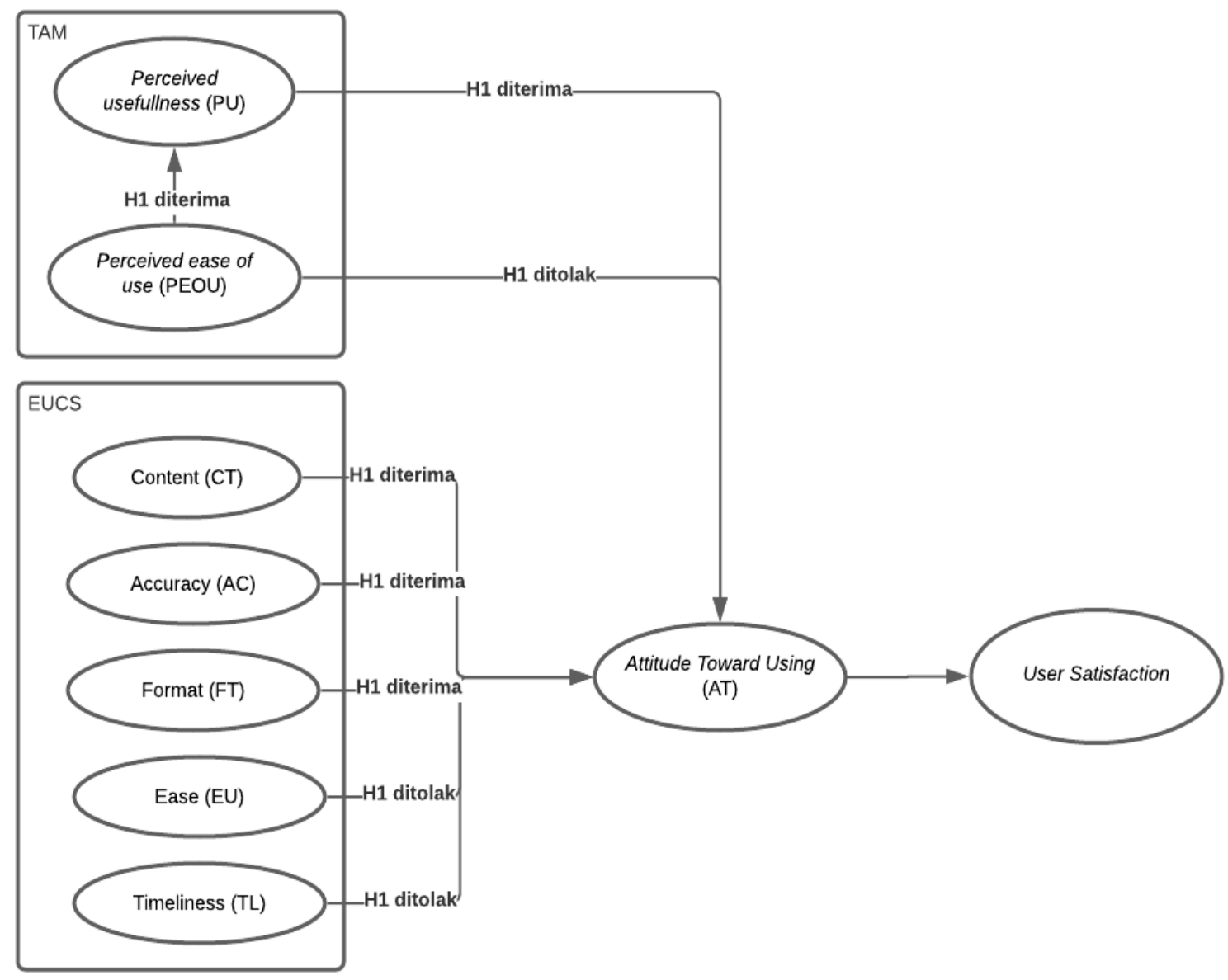

\section{Gambar 13. Model Hipotesis Penelitian Akhir}

Berdasarkan pada hasil analisa pada gambar 10 dengan menghilangkan hipotesa yang ditolak maka dibentuklah model struktural yang baru dimana konstruk PEOU, TL dan EU setelah dihapus dengan hubungan AT, seperti dapat dilihat pada gambar 11. 


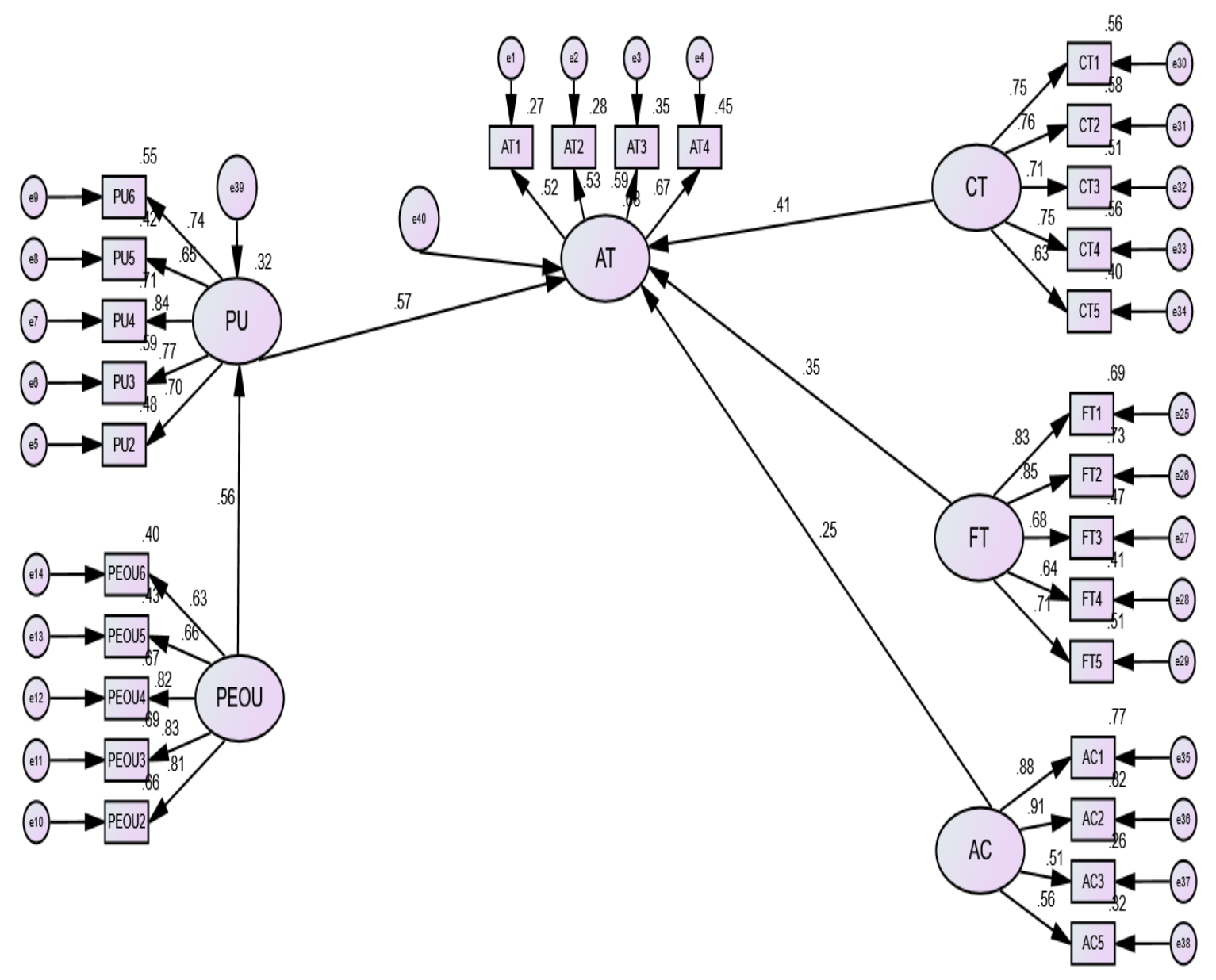

\section{Gambar 14. Model Penelitian Struktural Hipotesis Akhir}

Model penelitian struktural tahap pertama kemudian dilakukan pengujian ulang untuk mengetahui tingkat kesesuaiannya, hasil pengujian model struktural menggunakan SPSS AMOS 26 menghasilkan tingkat kesesuaian.

Pengujian ulang hipotesis penelitian berdasarkan pada model penelitian yang telah diulang, pengujian ini dilakukan untuk melihat hubungan diantara konstruk - konstruk yang ada dalam model penelitian. Dasar pengambilan keputusan diambil dengan melihat bobot regresi untuk konstruk terkait pada hasil pengujian menggunakan SPSS AMOS 26. Jika p > 0.05 maka H0 ditolak dan apabila $\mathrm{p}<$ 0.05 atau dilambangkan dengan $* * *$ maka $\mathrm{H} 1$ diterima seperti dipaparkan pada tabel 4.40 .

Tabel 11. Hasil Nilai Regression Weights Model Penelitian Hipotesis Akhir

\begin{tabular}{|c|c|c|c|c|c|}
\hline & Estimate & S.E. & C.R. & $\mathrm{P}$ & Label \\
\hline PU <--- PEOU & .522 & .059 & 8.925 & *** & par_24 \\
\hline AT <--- PU & .344 & .051 & 6.677 & $* * *$ & par_23 \\
\hline AT <--- AC & .119 & .037 & 3.219 & .001 & par_25 \\
\hline AT <--- FT & .184 & .042 & 4.355 & $* * *$ & par_26 \\
\hline AT <--- CT & .254 & .057 & 4.465 & *** & par_27 \\
\hline
\end{tabular}




\section{Analisis Pengaruh Total}

Pada model yang telah ditrimming terdapat tujuh variabel yang terdiri dari dua variabel eksogen (PU, AT) dan lima variabel endogen (PEOU, AC, CT, FT). Berikut pengaruh masing - masing variabel ;

1. Konstruk PEOU terhadap konstruk PU

Perceived Ease of Use (PEOU) terhadap memberi pengaruh positif sebesar 52,2\% terhadap Perceived Usefullness (PU).

2. Konstruk PU terhadap konstruk AT

Perceived Usefullness (PU) terhadap memberi pengaruh positif sebesar $34,4 \%$ terhadap Attitude Toward Using (AT).

3. Konstruk CT terhadap konstruk AT

Content (CT) terhadap memberi pengaruh positif sebesar 25,4\% terhadap Attitude Toward Using (AT).

4. Konstruk AC terhadap konstruk AT

Accuracy (AC) terhadap memberi pengaruh positif sebesar 11,9\% terhadap Attitude Toward Using (AT).

5. Konstruk FT terhadap konstruk AT

Format (FT) terhadap memberi pengaruh positif sebesar 18,4\% terhadap Attitude Toward Using (AT).

\section{Kesimpulan}

Berdasarkan hasil pengolahan dan analisis yang dilakukan dapat disimpulkan bahwa dari 8 hipotesis yang diajukan ada beberapa hipotesis yang diterima dan ada yang ditolak. Sesuai dengan rumusan permasalahan yang telah diuraikan di awal terjawab bahwa hasil dari analisis dengan menggunakan metode TAM dan EUCS menunjukan a.) persepsi kemudahan penggunaan (PEOU) memberi pengaruh positif sebesar 52,2\% terhadap persepsi kegunaan (PU), b.) persepsi kegunaan (PU) memberi pengaruh positif sebesar 34,4\% terhadap sikap (AT), c.) isi (CT) memberi pengaruh positif sebesar 25,4\% terhadap sikap (AT), d.) keakuratan (AC) memberi pengaruh positif sebesar $11,9 \%$ terhadap sikap (AT), e.) tampilan (FT) memberi pengaruh positif sebesar $18,4 \%$ terhadap sikap (AT), sehingga bisa disimpulkan bahwa 5 hipotesis tersebut memiliki berpengaruh terhadap kepuasan mahasiswa dalam menggunakan Google Classroom.

\section{Ucapan Terima Kasih}

Terima kasih penulis sampaikan kepada Kementerian Riset dan Teknologi / Badan Riset dan Inovasi Nasional (Kementerian Ristek / BRIN) yang telah memberikan dana hibah penelitian Skema Penelitian Dosen Pemula (PDP) Tahun 2021. Selanjutnya, terima kasih kepada ketua dan staff LPPM Universitas Informatika dan Bisnis Indonesia yang telah memfasilitasi kegiatan PDP yang telah membimbing penelitian ini mulai penyusuan proposal hingga laporan penelitian.

\section{Referensi}

[1] L. Sofyana and A. Rozaq, "Pgri Madiun," Pembelajaran Daring Komb. Berbas. Whatsapp Pada Kelas Karyawan Prodi Tek. Inform. Univ. Pgri Madiun, vol. 8, pp. 81-86, 2019.

[2] A. B. Hakim, "Efektifitas Penggunaan E-Learning Moodle , Google Classroom Dan Edmodo," vol. 2, pp. 1-6, 2016.

[3] E. Yulianingsih, "E-Learning Menggunakan Technology Acceptance Model Dan End User Computing Satisfaction," J. Ilm. MATRIK, vol. 18, no. 1, pp. 27-42, 2016.

[4] K. N. M. N. Masitah and I. Ilhamsyah, "Evaluasi Kepuasan Pengguna Siakad Universitas Tanjungpura Menggunakan Integrasi Technology Acceptance Model (Tam) Dan End-User Computing Satisfaction (Eucs)," Coding J. Komput. dan Apl., vol. 8, no. 2, pp. 11-21, 2020, doi: 10.26418/coding.v8i2.41217.

[5] A. E. Hadisuwarno and R. Bisma, "Analisis penerimaan pengguna aplikasi e-Kinerja dengan metode TRAM dan EUCS pada kepolisian Analysis of user acceptance of e-Kinerja applications with the TRAM and EUCS methods at the police," J. Ilm. Sist. Inf., vol. 10, no. 2, pp. 93-109, 2021. 
[6] A.H. Indrakusuma and A. R. Putri, E-Learning -Teori dan Desain. Tulungngagung: STKIP PGRI, 2016.

[7] B. Lee, "Blended Learning through Google Classroom," Int. J. Educ. Pedagog. Sci., vol. 14, no. 4 , pp. 220-226, 2020.

[8] Sugiyono, Metode Penelitian Kombinasi. Bandung: Alfabeta, 2016.

[9] C. S. P.L, Analisis Penerimaan Pengguna Akhir Dengan Menggunakan Technology Acceptance Model Dan End User Computing Satisfaction Terhadap Penerapan Sistem Core Banking Pada Bank Abc Tesis. 2006.

[10] S. Santoso, Panduan Lengkap SPSS 26. Jakarta: Elex Media Komputindo, 2020.

[11] S. Santoso, Analisis SEM menggunakan AMOS. Jakarta: Elex Media Komputindo, 2014.

[12] A. P. Sari and M. A. Syamsuddin, "Analisis Faktor End-User Computing Satisfaction Terhadap Kepuasan Pengguna: Studi Kasus Kantor Pelayanan Pajak Madya Balikpapan,” J. Pajak Indones., vol. 1, no. 2, pp. 92-101, 2017.

[13] T. Loanata and K. G. Tileng, "Pengaruh Trust dan Perceived Risk pada Intention To Use Menggunakan Technology Acceptance Model (Studi Kasus Pada Situs E-Commerce Traveloka)," JUISI J. Inform. dan Sist. Inf., vol. 02, no. 2460-1306, p. 10, 2016.

[14] T. Farahat, "Applying the Technology Acceptance Model to Online Learning in the Egyptian Universities," Procedia - Soc. Behav. Sci., vol. 64, pp. 95-104, 2012, doi: 10.1016/j.sbspro.2012.11.012.

[15] Budiman, "Pengaruh Pemanfaatan Sistem Akademik Online Terhadap Kepuasan Mahasiswa Menggunakan Technology Acceptance Model (TAM)," Maj. Bisnis Dan IPTEK, vol. 9, no. 2, 2016, [Online]. Available: https://jurnal.stiepas.ac.id/index.php/bistek/article/view/77.

[16] Z. Niqotaini, "Analisis Penerimaan Dan Penggunaan Media Pembelajaran Augmented Reality Dengan Menggunakan Model UTAUT-2 (Studi Kasus: SMP dan SMA Mutiara Bunda Bandung)," Technol. J. Ilm., vol. 12, no. 1, p. 4, 2021, doi: 10.31602/tji.v12i1.4175. 